\title{
Architects of Continental Seapower
}

This book describes and analyses two iconic figures in twentieth-century naval history: the German Admiral Alfred von Tirpitz and the Russian Admiral Sergei Gorshkov.

It examines the men, what they thought and wrote about seapower, the fleets they created and the strategic consequences of what they did. More broadly, it draws on the respective histories of the post-1897 Imperial German Navy and the post-1956 Soviet Navy to examine the continental bid for large-scale seapower. The work argues that both individuals built navies that did not, and could not, fulfil the objectives for which they were created. Drawing on the legacies of both men, the book also develops some wider ideas about the creation of large navies by continental states, with cautionary lessons for today's emerging powers, India and China. Both admirals have received book-length biographies, but this is the first attempt at a comparative study and the first to draw broader strategic lessons from their respective attempts as continental navalists to challenge maritime states.

This book will be of much interest to students of naval history, strategic studies and International Relations.

Captain Jeremy Stocker is an Associate Fellow of the Royal United Services Institute in London, and an independent defence analyst and naval historian. This is his second book. 


\title{
Corbett Centre for Maritime Policy Studies Series \\ Series Editors: Greg Kennedy, Tim Benbow and \\ Jon Robb-Webb \\ Defence Studies Department, Joint Services Command and \\ Staff College, UK
}

The Corbett Centre for Maritime Policy Studies Series is the publishing platform of the Corbett Centre. Drawing on the expertise and wider networks of the Defence Studies Department of King's College London, and based at the Joint Services Command and Staff College in the UK Defence Academy, the Corbett Centre is already a leading centre for academic expertise and education in maritime and naval studies. It enjoys close links with several other institutions, both academic and governmental, that have an interest in maritime matters, including the Developments, Concepts and Doctrine Centre (DCDC), the Naval Staff of the Ministry of Defence and the Naval Historical Branch. The centre and its publishing output aims to promote the understanding and analysis of maritime history and policy and to provide a forum for the interaction of academics, policy-makers and practitioners. Books published under the aegis of the Corbett Centre series reflect these aims and provide an opportunity to stimulate research and debate into a broad range of maritime-related themes. The core subject matter for the series is maritime strategy and policy, conceived broadly to include theory, history and practice, military and civil, historical and contemporary, British and international aspects. As a result, this series offers a unique opportunity to examine key issues such as maritime security, the future of naval power and the commercial uses of the sea, from an exceptionally broad chronological, geographical and thematic range. Truly interdisciplinary in its approach, the series welcomes books from across the humanities, social sciences and professional worlds, providing an unrivalled opportunity for authors and readers to enhance the national and international visibility of maritime affairs, and provide a forum for policy debate and analysis.

\author{
Architects of Continental Seapower \\ Comparing Tirpitz and Gorshkov \\ Captain Jeremy Stocker
}

Naval Diplomacy in the 21st Century

A Model for the Post-Cold War Global Order

Kevin Rowlands

\section{Europe, Small Navies and Maritime Security}

Balancing Traditional Roles and Emergent Threats in the 21st Century

Edited by Robert McCabe, Deborah Sanders and Ian Speller

For more information about this series, please visit: www.routledge.com/Corbett-Centrefor-Maritime-Policy-Studies-Series/book-series/CCMPSS 


\title{
Architects of Continental Seapower \\ Comparing Tirpitz and Gorshkov
}

\author{
Captain Jeremy Stocker
}

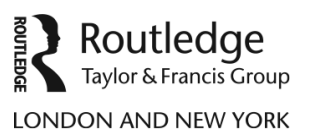


First published 2021

by Routledge

2 Park Square, Milton Park, Abingdon, Oxon OX14 4RN

and by Routledge

52 Vanderbilt Avenue, New York, NY 10017

Routledge is an imprint of the Taylor \& Francis Group, an informa business

(c) 2021 Captain Jeremy Stocker

The right of Captain Jeremy Stocker to be identified as author of this work has been asserted by him in accordance with sections 77 and 78 of the Copyright, Designs and Patents Act 1988.

All rights reserved. No part of this book may be reprinted or reproduced or utilised in any form or by any electronic, mechanical, or other means, now known or hereafter invented, including photocopying and recording, or in any information storage or retrieval system, without permission in writing from the publishers.

Trademark notice: Product or corporate names may be trademarks or registered trademarks, and are used only for identification and explanation without intent to infringe.

British Library Cataloguing-in-Publication Data

A catalogue record for this book is available from the British Library

Library of Congress Cataloging-in-Publication Data

A catalog record has been requested for this book

ISBN: 978-0-367-53127-0 (hbk)

ISBN: 978-1-003-08055-8 (ebk)

Typeset in Times New Roman

by Wearset Ltd, Boldon, Tyne and Wear 
Dedicated to the memory of Rear Admiral Richard Hill, like Admiral Gorshkov a late-twentieth-century theorist of sea power with enduring relevance. 


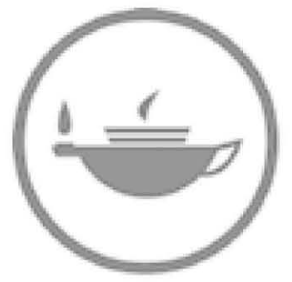

Taylor \& Francis Taylor \& Francis Group

http://taylorandfrancis.com 


\section{Contents}

Acknowledgements

ix

Preface

1 Introduction

PART I

Careers

2 Alfred von Tirpitz

3 Sergei Gorshkov

PART II

Writings

4 Tirpitz - his writings 51

5 Gorshkov - his writings $\quad 74$

PART III

Fleets 105

6 The Imperial German Navy 107

7 The Soviet Navy 122

PART IV

Consequences 141

8 Consequences and assessment - Tirpitz 143

9 Consequences and assessment - Gorshkov 164 
viii Contents

PART V

$\begin{array}{lr}\text { Conclusions } & 179\end{array}$

10 The continental experience with seapower 181

Appendices 196

(i) Dienstschrift IX 196

(ii) Navies in war and peace $\quad 205$

Bibliography 215

(i) Tirpitz 215

(ii) Gorshkov 218

(iii) General 221

Index 223 


\section{Acknowledgements}

My thanks are due to my friend and colleague Captain Kevin Rowlands of the Royal Navy, himself an expert on Gorshkov. He kindly reviewed each chapter as it was written and provided invaluable suggestions for improvement as well as much needed encouragement. I am also grateful to the two anonymous reviewers whose comments further improved the text.

The Corbett series editors, especially Dr Tim Benbow, provided additional suggestions and help to speed the draft through the process.

At Routledge, Andrew Humphrys and Bethany Lund-Yates were generous with their time and expertise in guiding the original manuscript through to publication. Permission to reproduce extracts from Sergei Gorshkov's works published by the US Naval Institute Press was speedily obtained, thanks to Liese Doherty.

Dr Tobias Ebker, a medical colleague of my wife's, helped me to make sense of the nineteenth-century German prose in Dienstschrift IX.

My final, and greatest, thanks are to my wife Judith, for everything. 


\section{Preface}

The idea that there are useful comparisons to be drawn between Admirals Tirpitz and Gorshkov is not a new one. But, so far as the author is aware and certainly in the English language, this is the first substantial work to undertake a comparative study of the two men, their writings, the fleets they created and the strategic consequences of what they did. It makes no claims to original, primarysource research, not least because the author's command of German extends little beyond ordering a beer and his Russian not even that far. Instead, it tries to build on the research and analysis of others that, other than some passing comments on their similarities, deals with either Tirpitz or Gorshkov. The book concludes with an assessment of the two men and their navies, and what their legacies may have to tell us about the continental experience in generating largescale seapower.

The fleets they built resulted in classic arms races with their maritime opponents. How the two arms races conducted within cold wars have been treated by historians are, despite the strong parallels that this book seeks to highlight, very different. This is only partially explicable by the different passages of time since the events in question - a century since Tirpitz, a third of that time since Gorshkov. The German archives covering the Imperial German Navy have been open for many years and much of the key material has been translated into English. Such is the importance of the lead-up to war in 1914, including its naval aspects, that the period has spawned a huge literature. Beginning with Jonathan Steinberg's Yesterday's Deterrent in 1965, scholars of both German history and of twentieth-century naval history have conducted a vigorous debate about the origins of and explanations for the extraordinary phenomenon that was the "Tirpitz Plan". Writers have put different emphases on domestic and international motivations, on the influence of contemporary political and social assumptions, the role of competing imperialisms and economic jealousies, "navalist" enthusiasms and objective analysis of genuine security needs. This work does not reopen this debate, but does draw on it to make the appropriate comparisons with the later Russian experience. On Tirpitz himself, Patrick Kelly's 2011 biography is perhaps the best. For the most important original source documents, on both the German and British sides, a recent volume from the Navy Records Society in the UK, The Naval Route to the Abyss, is 
invaluable. It also contains a good historiographical review of the literature and the terms of the debate.

When it comes to Admiral Gorshkov and the Cold War Soviet Navy, it is a rather different story. We do have English translations of his most important writings, especially Red Star Rising at Sea (a compendium, with Western commentary, of 11 articles previously published in journals in both the Soviet Union and the United States) and a later book, The Sea Power of the State. There is also plenty of source material, some of it originally intelligencederived, on the Soviet Fleet, though most of it contemporaneous when the subject was of current, and urgent, interest. Plenty was written at the time about Soviet naval strategy and capabilities and this literature remains relevant, despite lacking the benefit of perspective that comes with the passage of time. We do have a recent biographical work on Sergei Gorshkov by Norman Polmar and others, but it is as much about the history of the Soviet Navy as it is the man himself. Though the salient facts about his life and career can be pieced together, we simply do not know as much about him as we do Tirpitz. This book tries to say as much about Gorshkov as can sensibly be established and deduced. We are similarly denied much original source material from Russian archives, though there is some secondary literature in English by Russian authors drawing upon it. Perhaps most surprising, the Soviet Navy, despite the attention paid to it by NATO at the time, hardly features in general histories of the Cold War. This may be, in part, because the arms race at sea was less central to the wider confrontation than the nuclear balance or the Inner German Border. It may also be because much of what went on at sea was, and remains, highly classified and little understood beyond those who played a part in it.

Historical study is worthwhile for its own sake. It has added relevance when it has something to say about contemporary issues. Two decades into the twenty-first century, India and China, two continental-scale states with long coastlines, are building large navies and becoming more assertive at sea. The rise of China in particular indicates that American dominance at sea, at least in the Asia-Pacific region, may not go on unchallenged. A recent work by Chinese writer Colonel Xu Qiyu suggests - if only by implication - that history has something to teach his country today. The author of this work agrees.

Tirpitz and Gorshkov both had large ships named after them, but not until after their deaths. These later ships, to a considerable extent, represented the kinds of navies the two admirals wanted to build. Neither realised the hopes vested in them, just as neither fleet had done.

A few words on terminology may be useful. "Sea Power", "Seapower", "Naval Power", "Maritime Power", "Continental Power" and "Insular" all appear throughout the literature on the history and strategy of these interrelated topics and are used extensively in this book. While not wishing to engage in an extended doctrinal debate concerning precise but overlapping meanings, we should understand broadly what we are talking about. In this work, "continental power" or "continental state" is taken to mean a country with extensive land frontiers and strategically significant neighbours. Its access to the open seas is 


\section{xii Preface}

likely to be constrained, both by geography and by other states and its security will likely rest on its army. "Insular" means a state that is either literally an island (like Britain or Japan) or whose neighbours on land are not of significant strategic concern to it (like the United States) and consequently is, in strategic terms, an island albeit one of continental scale. A "maritime power" is one whose principal strategic interests lie at sea and whose navy is likely to be the basis of its security. "Naval power" is the strength of a country's navy and $a$ "naval power" is a state with a significant navy. "Seapower" is a little broader than naval power, encompassing wider measures of strength at sea than just a navy and a "sea power" is one that can exercise seapower. Colin Gray, drawing on an earlier and fuller description by Herbert Richmond, puts it this way: "Sea power is the ability to use the seas and oceans for military or commercial purposes and to preclude an enemy from the same." The respective meanings of all these terms can blur somewhat, though they can generally be deduced from the context in which they are used.

In order to clarify matters, in this volume the emphasis is on the distinction between Maritime and Continental states, noting that some countries do not neatly fit either categorisation. Seapower refers to the ability to act at, and from, the sea. Other than in relation to what others have said on the subject, reference to states as "sea powers" has been deliberately avoided in order to escape confusion.

\section{Note}

1 Colin S. Gray The Leverage of Sea Power: The Strategic Advantage of Navies in War New York: The Free Press, 1992 p. 4. 


\section{Introduction}

During the twentieth century, two quintessentially "continental" states embarked upon ambitious naval building programmes that, within a few years, produced the second-largest navies of their times. In each case, the creation of the new fleet was largely conceived and directed by a single man: Grand Admiral Alfred von Tirpitz in pre-First World War Germany and Admiral of the Fleet of the Soviet Union Sergei Gorshkov in post-Second World War USSR.

Neither Tirpitz nor Gorshkov achieved much as seagoing admirals. Tirpitz never saw combat and Gorshkov's distinguished wartime career was conducted largely from ashore in what is today Ukraine. In this they reflected the recent histories of their respective Services. The Prussian Navy played no role in the wars of German unification and, Gorshkov's conduct of amphibious and riverine operations aside, the Soviet Navy was almost entirely ineffective during the Second World War. "In short, the [Prussian or Soviet] Navy had little to be proud of." Instead of sea command, both men became two of the leading naval figures of the twentieth century as a result of their political and administrative skills, creating in each case large navies in countries with little or no naval tradition and for which, arguably, naval forces were peripheral to their real security needs.

Tirpitz and Gorshkov were both prolific writers, the latter especially so. The former's main contribution to naval strategic thought was his famous "Risk Theory", a concept of deterrence whereby an inferior power might successfully deter a stronger one and thus obtain some strategic freedom of manoeuvre. The Risk Theory itself has become thoroughly discredited, in part because it was meant to deter a "threat" it was itself responsible for creating and in part because Germany lost the ensuing war having failed to actually deter its opponent. But the principle, on which the Risk Theory rested, that you can deter a stronger opponent, remains valid. It lies at the heart, for example, of British nuclear deterrence policy. Gorshkov's strategic thought is a good deal more sophisticated and has left a much more positive legacy. His comprehensive exposition of seapower encompasses all aspects of the marine environment for political, diplomatic, economic and military purposes. In particular, he provides an understanding of what it is to look out to sea from an essentially continentalist perspective, in contrast to the more insular or sea-based views of many Western seapower thinkers. 


\section{Introduction}

The Imperial German Navy and the Soviet Navy became the second most powerful fleets of their respective eras. In doing so, they took rather different paths. Tirpitz tried to imitate his larger rival, building a smaller and, despite some specific technical advantages, qualitatively inferior fleet. Gorshkov rightly and inevitably (for he had little alternative) created a navy that was that perennial naval objective, a "balanced" fleet, but one that looked very different to its opponent. Each fleet was created in the midst of a technical-military revolution; in the German case the "Dreadnought" all-big gun revolution accompanied by the appearance of the submarine and in the Soviet case the naval revolution brought about by nuclear propulsion, nuclear weapons, computers and guided missiles. Both men's life's works ended in failure and both navies rusted away, the Imperial German Navy at the bottom of Scapa Flow in Scotland, the Soviet Navy in its own ports. Tirpitz lived to see the unravelling of his plans, though Gorshkov did not.

Imperial Germany and Soviet Russia were, and their successor states today remain, largely but not entirely land-locked countries. Germany sits in the heart of Europe with extensive land frontiers on all sides and just two small coastlines in the north, facing the Baltic and North Seas either side of the Danish peninsula. Russia forms the largest part of the Eurasian landmass with the longest land frontiers of any country in the world. In the north, a huge coastline is normally ice-bound and beyond it lies the permanently frozen polar region. It cannot really be considered a coast in a strategic sense. Russia's more "normal" coasts in the Barents Sea, the Baltic, the Far East and the Black Sea are small and widely separated and all but the last are ice-bound for part of the year anyway.

This geography dictates that the security of both Germany and Russia has always been determined on land and that their respective armies have been the basis of their national power and independence. Indeed, their attempts to acquire large-scale seapower during the periods under consideration have been described as "ahistorical" and their navies a "luxury" or an "expensive toy". Tirpitz and Gorshkov would both react angrily at such suggestions, betraying a sensitivity that indicated they had their own internal battles to fight to secure the naval building programmes they wanted. Gorshkov, for example, said "... hostile propaganda continually promulgated the idea that Russia is not a maritime country, but rather a continental one and therefore does not need a navy". ${ }^{3}$ The case for a navy capable of deploying away from the homeland was strengthened when Imperial Germany and Soviet Russia were both embarrassed by their inability to act in events far away, such as the Boer War in the former case and the Cuban Missile Crisis in the latter. ${ }^{4}$

Tirpitz and Gorshkov both claimed that their respective navies were “defensive". The German High Seas Fleet was, if Tirpitz's public statements were to be believed, meant to defend German interests from a British preemptive attack, prompted in part by economic jealousy. It would also allow Germany to claim its rightful "place in the sun". Gorshkov insisted that the Soviet fleet would defend the Motherland from aggressive capitalist imperialism, 
as well as project Socialist influence out into the "World Ocean". In each case, great power status required a large navy. Whatever the truth of these claims, the respective naval expansion programmes appeared threatening to their established maritime rivals and they reacted accordingly. The results were classic arms races conducted within the context of broader "cold wars".

The fleets created by Tirpitz and Gorshkov therefore had profound effects at the time: diplomatic, political, economic and strategic. Each posed a substantial challenge to the dominant maritime power of their day, respectively Great Britain and later the United States. Under Tirpitz and Gorshkov, the German and Soviet fleets went from modest, essentially coastal defence forces (though the Soviets already had a huge force of small submarines) to the navies of "world powers". By the late 1970s, "The Russian bear ha[d] grown webbed feet." The same had been true of the German imperial eagle by the early 1910s. But there was an important difference. Tirpitz's fleet stayed in the Baltic and the North Sea. Gorshkov's ships were to be found all over the world.

Imperial Germany and Soviet Russia were not the first continental states to acquire large navies. Russia under the Tsars, beginning with Peter the Great at the start of the eighteenth century, made intermittent efforts to become a significant sea- as well as landpower. Spain, the Netherlands and France, all with land and sea borders and overseas empires, became naval powers of note and all fought England or Britain at sea between the sixteenth and nineteenth centuries. The significant exception in Europe is Germany, which had only been unified in 1871 and its predecessor state, Prussia, had never shown much interest in naval forces.

British-American strategic analyst Colin Gray observes: "The strategic value of naval power cannot be derived from the isolated study of ships, navies or sea power. Naval power, on whatever scale of provision, is valuable only if a country needs it." ${ }^{6}$ This book examines the question, among others, of whether Germany or Russia "needed" the seapower they got, and whether each state's security interests were furthered as a consequence.

Winston Churchill said of the Imperial German Navy: "The determination of the greatest military Power on the [European] Continent to become at the same time at least the second naval Power was an event of first magnitude in world affairs."7 The same could be said of the Soviet Navy later in the same century. Both countries, in a relatively short space of time, became "a highly competitive and competent sea power." In the process, both countries were presented with opportunities, and opportunity costs, in terms of the decisions they made - and those they did not.

The result in both cases was an arms race, in which the continental challengers (Germany and Russia) were decisively beaten by their established and dominant maritime rivals (Britain and the United States).

Historical views of Tirpitz and the Imperial German Navy tend to be overshadowed by what we now know followed the Anglo-German naval arms race: the First World War. Such an outcome was not, of course, inevitable and in fact the arms race had already peaked and, arguably, stabilised before war came. 


\section{Introduction}

Tirpitz's influence was certainly already on the wane. The Anglo-German "cold war" was followed by a "hot war" and then the collapse of Imperial Germany.

Gorshkov's Soviet Union was later engaged in another cold war, this time with the United States and its allies, including Britain. That cold war, too, featured a naval arms race between the protagonists. Gorshkov's influence, too, peaked before the Cold War was over, though the latter ended, not in a "hot" war, but in the peaceful collapse of the Soviet Union.

From these two important case studies it is possible to make some general observations about the experience, and future prospects, of large continental states when they seek to generate large-scale seapower. Chapter 10 seeks to do this.

Before examining in detail the work of each man and its consequences, it is important to note that neither operated in an intellectual or historical vacuum and that there were precedents for what they thought and did. Conflict between predominantly continental (or land) and predominantly maritime (or sea) powers is not new. That between Sparta and Athens during the Peloponnesian War is often cited as an early example, though in that case it was the maritime power (Athens) that was rising and seeming to challenge land-oriented Sparta whereas in the two instances examined in this book the maritime powers were the established ones facing continental challengers.

Ideas about the "inevitable" conflict between rising and established powers go as far back as Thucydides' history of the Peloponnesian War. ${ }^{9}$ Though the war was between the maritime Athenian Empire and the continental Spartan Empire little was said, however, about this aspect of the conflict perhaps because then, and for many centuries thereafter, war at sea was regarded as largely an extension of warfare on land.

The eighteenth-century conflicts between Britain and France might be another example of maritime/continental conflict, though it will be argued later that France is a poor example of a "continental" state due to its extensive sea as well as land frontiers and its easy access to the high seas. But the French rivalry with Britain certainly produced some later theorising along continental/land and maritime/sea power lines.

It was not until the late-nineteenth century that writers such as Alfred Mahan and Philip Colomb provided a substantial body of historically-based writings about the exercise of seapower. ${ }^{10}$ France's inability to successfully challenge Britain at sea, despite a larger population base, prompted distinct thinking along what today we would call "asymmetric" lines. France's dilemma was that, with militarily significant neighbours on land, it could never devote sufficient defence resources to its navy to make a success of war at sea against Britain in the conventional (i.e. battlefleet) manner. This was to be Germany's problem as well early in the next century.

Starting with Baron Grivel's De La Guerre Maritime in 1869 and developed later by Admiral Theophile Aube (Minister of Marine from 1886), the French developed what came to be known as Guerre de Course (war on commerce). The Jeune École ("young school”) argued that attacks against Britain's seaborne 
commerce was always a more promising strategy than engaging its battlefleet with a (weaker) French one. In addition, the dominance of the British battlefleet itself could be challenged by asymmetric means enabled by new technologies such as mines, torpedoes and, eventually, submarines. By such methods Britain would be prevented from once again blockading French ports. ${ }^{11}$ Exactly this prospect would later cause the Royal Navy to change from "close" to "distant" blockade of Germany.

As we will see in later chapters, this combination of coastal defence and overseas commerce-raiding was essentially the approach adopted by Germany and Russia, before first Tirpitz and then Gorshkov became more ambitious for their respective countries at sea. They cannot have been unaware of this "continentalist" approach and indeed Tirpitz explicitly rejected it. But it was the strategy of a weaker power at sea and neither man was prepared to concede an inferior status.

\section{Notes}

1 George E. Hudson "Soviet Naval Doctrine under Lenin and Stalin" Soviet Studies 28:1 (January 1976) p. 60.

2 Holger H. Herwig "Luxury Fleet": The Imperial German Navy 1888-1918 London: George Allen \& Unwin, 1980 \& Sergei Chernyavskii "The Era of Gorshkov: Triumph and Contradictions" The Journal of Strategic Studies (JSS) 28:2 (April 2005) pp. 281-308. It was Winston Churchill who originally applied the term "luxury fleet" to the German Navy, in 1912.

3 S. G. Gorshkov "Russia's Road to the Sea" the second article in a series of 11 later republished in Herbert Preston (ed.) Red Star Rising at Sea Annapolis MD: Naval Institute Press, 1974 p. 12. Henceforth cited as RSRS.

4 See Chapters Two and Four, respectively.

5 Norman Polmar (ed.) The Modern Soviet Navy London: Arms and Armour Press, 1979 p. 11.

6 Colin S. Gray The Navy in the Post-Cold War World University Park PA: The Pennsylvania State University Press, 1994 p. 161.

7 Winston Churchill The World Crisis 1911-1914 cited in John H. Maurer "Averting the Great War?: Churchill's Naval Holiday" Naval War College Review (NWCR) 67:3 (Summer 2014) p. 27.

8 Evan Park "The Nationalist Fleet: Radical Nationalism and the Imperial German Navy from Unification to 1914" Journal of Military and Strategic Studies (JMSS) $16: 2(2015)$ p. 125.

9 Thucydides History of the Peloponnesian War Translated by Rex Warner London: Penguin Books, 1954.

10 Alfred Mahan The Influence of Seapower upon History 1660-1783 Boston MA: Little, Brown \& Co, 1890 \& Philip Colomb Naval Warfare London: Allen, 1899.

11 For a fuller discussion of the Jeune École and Guerre de Course, see Geoffrey Till, Seapower: A Guide for the Twenty-First Century London: Frank Cass, 2004 pp. 59-62. 


\section{Careers}

not be the only example of a foreign policy (Weltpolitik in this case) being pursued for domestic objectives.

More recently, Patrick Kelly has disputed this idea, suggesting that Tirpitz saw more limited objectives behind his fleet plan, though he certainly supported Weltpolitik and believed in the Navy as a unifying national institution in a still fragmented (and somewhat chaotic) Reich. But, whether by design or not, the "Tirpitz Plan" did boost industry ${ }^{82}$ and provided a nationalistic rallying-cause. It was also, of course, the Kaiser's pet project.

In one important respect, "Tirpitz remains an enigma." ${ }^{83}$ What was his final objective? Should his Risk Theory of deterrence, for all its obvious contradictions, be taken at face value, or was it a public rationale for something actually more ambitious? The fleet he wanted to build only made sense if it was directed against Britain, but which came first - the British "threat" or the fleet? Was Britain the reason for the fleet, or simply the justification for it? Tirpitz kept his own counsel, even among his closest colleagues. But he was a "navalist" who believed in naval power for its own sake. And he did give hints as to what his real aim might have been. There are occasional references in his private correspondence to "a fleet as strong as the English one". ${ }^{84}$

The fleet that Tirpitz created and the wider political, diplomatic and strategic consequences that flowed from it will be examined in later chapters.

\section{Notes}

1 The most comprehensive biography of Tirpitz to date is Patrick J. Kelly Tirpitz and the Imperial German Navy Bloomington IN: Indiana University Press, 2001.

2 Gordon A. Craig Germany 1866-1945 Oxford: Oxford University Press, 1981 p. 303.

3 "Fleet" perhaps overstates the case. The Prussian Navy of the 1860 s consisted of a small miscellany of vessels, many of them obsolete.

4 Alfred von Tirpitz My Memoirs Vol I London: Hurst \& Blackett, 1919 p. 10.

5 Kelly Tirpitz p. 28.

6 For details of the ships Tirpitz served in during his career, see Roger Chesnau \& Eugene Kolesnik (eds) Conway's All the World's Fighting Ships 1860-1905 London: Conway Maritime Press, 1979.

7 Kelly Tirpitz p. 50.

8 Kelly Tirpitz p. 62.

9 Michael Epkenhans Tirpitz: Architect of the German High Seas Fleet Washington, DC: Potomac Book, 2008 p. 16.

10 Patrick Kelly "Strategy, Tactics and Turf Wars: Tirpitz and the Oberkommando der Marine, 1892-1895" The Journal of Military History (JMH) 66:4 (October 2002) p. 1040.

11 Epkenhans p. 17.

12 Jonathan Steinberg Yesterday's Deterrent: Tirpitz and the Birth of the German Battle Fleet London: Macdonald, 1965 p. 69.

13 See Appendix (i).

14 Kelly JMH 66:4 p. 1034.

15 Robert K. Massie Dreadnought: Britain, Germany and the Coming of the Great War New York: Random House, 1991 p. 164.

16 Ian Speller Understanding Naval Warfare Abingdon: Routledge, 2014 pp. 58-61.

17 Admiral Knorr "High Command of the Navy, Report to the Emperor" 28 November in Matthew Seligmann et al. (eds) The Naval Route to the Abyss: The Anglo-German 
Naval Race 1895-1914 Farnham: Ashgate for the Navy Records Society, 2015. (Henceforth referred to as NRS Abyss) pp. 15-30.

18 Epkenhans Tirpitz p. 32.

19 Kelly Tirpitz p. 112.

20 Kelly $J M H 66: 4$ p. 1058.

21 Steinberg p. 124.

22 Paul Kennedy The Rise of the Anglo-German Antagonism, 1860-1914 London: George Allen \& Unwin, 1982 p. 223.

23 Robert J. Art "The Influence of Foreign Policy on Seapower: New Weapons and Weltpolitik in Wilhelminian Germany" Robert J. Art \& Kenneth N. Waltz (eds) The Use of Force: International Politics and Foreign Policy (2nd edition) Lanham MD: University Press of America, 1983 p. 182.

24 Peter Padfield The Great Naval Race: Anglo-German Naval Rivalry 1900-1914 St Albans: Granada Publishing, 1974 p. 41.

25 Gary E. Weir Building the Kaiser's Navy: The Imperial Naval Office and German Industry in the von Tirpitz Era, 1890-1919 Annapolis MD: Naval Institute Press, 1992 p. 21.

26 Kelly Tirpitz p. 128.

27 See Chapter 4.

$28 \mathrm{Up}$ to this point the Kaiser tended to favour cruisers.

29 Rear Admiral Tirpitz "Memorandum by the State Secretary of the Imperial Navy Office" June 1897, NRS Abyss pp. 42-52.

30 Steinberg pp. $129 \& 133$.

31 Dirk Bonker Militarism in a Global Age: Naval Ambitions in Germany and the United States Before World War I Ithaca NY: Cornell University Press, 2012 p. 202.

32 Weir p. 84.

33 Kelly Tirpitz p. 167.

34 Bonker pp. 184-185.

35 Massie p. 197.

36 Cited in Kelly Tirpitz p. 282.

37 Tirpitz memorandum June 1897 p. 42.

38 The full text of the 1898 Act, the "Law Concerning the German Fleet", is in NRS Abyss pp. 49-52.

39 Kelly Tirpitz p. 138.

40 Hew Strachan The First World War Volume I: To Arms Oxford: Oxford University Press, 2001 p. 12.

41 Steinberg p. 148.

42 NRS Abyss p. 111.

43 What today would be called a "drumbeat".

44 Kelly Tirpitz p. 179.

45 Amendment to the Act Concerning the German Navy of 10 April 1898, 14 June 1900 NRS Abyss pp. 59-80.

46 See Chapter 4.

47 Kelly Tirpitz Chapter 11.

48 Kelly Tirpitz p. 236.

49 The wider consequences of the growth of the German Navy are examined in Chapter 8.

50 In 1807, the British had attacked the neutral Danish fleet to prevent it falling into the hands of the French.

51 Kelly Tirpitz p. 259.

52 Padfield p. 136.

53 Kennedy Anglo-German Antagonism p. 422.

54 Massie p. 685.

55 Padfield p. 223. 


\section{Careers}

56 For fuller accounts of the 1909 Naval "Scare", see Kelly Tirpitz pp. 299-306 \& Massie pp. 609-625.

57 Kelly Tirpitz p. 329.

58 Hence the title of Holger Herwig's "Luxury" Fleet.

59 Weir p. 105.

60 NRS Abyss p. 397.

61 For details of British and German Dreadnought designs, see Randal Gray (ed.) Conway's All the World's Fighting Ships 1906-1921 London: Conway Maritime Press, 1985 pp. 21-35 \& 145-154.

62 Chapter 8.

63 NRS Abyss p. 400.

64 Epkenhans p. 54.

65 Kelly Tirpitz p. 371.

66 Tirpitz Memoirs Vol. II p. 119.

67 Strachan p. 412.

68 Herwig p. 159.

69 Paul G. Halpern A Naval History of World War I Annapolis MD: Naval Institute Press, 1994 p. 290.

70 Weir p. 143.

71 Kelly Tirpitz p. 397.

72 Herwig pp. 164-165.

73 Kelly Tirpitz p. 408.

74 Kelly Tirpitz p. 427.

75 Art p. 183.

76 Craig p. 310.

77 Paul Kennedy Strategy and Diplomacy 1870-1945 London: Fontana, 1983 p. 152.

78 Kelly Tirpitz p. 195.

79 Steinberg p. 55

80 Kelly Tirpitz p. 3.

81 Ruddock F. Mackay "Historical Reinterpretations of the Angle-German Naval Rivalry, 1897-1914" in Gerald Jordan (ed.) Naval Warfare in the Twentieth Century 1900-1945 London: Croom Helm, 1977 p. 42.

82 Michael Epkenhans "Technology, Shipbuilding and Future Combat in Germany, 1880-1914" in Phillips Payson O'Brien (ed.) Technology and Naval Combat in the Twentieth Century and Beyond London: Frank Cass, 2001 pp. 53-68.

83 Padfield p. 209.

84 Kennedy Strategy and Diplomacy p. 160. 


\section{Careers}

he relied on political sponsorship and was responding to the strategic circumstances of his time, Gorshkov was that "energetic and erudite" individual and there is little evidence that any other individual was available to perform in the same way.

Gorshkov's personal impact was highlighted by a Time magazine cover story in February 1968. Gorshkov had "totally reshaped the Soviet Union's once conservative naval strategy and transformed the fleet into the most effective and flexible arm of Soviet foreign policy". ${ }^{88}$ This judgement may have been a little premature - the Brezhnev era fleet was only starting to appear - but not by much. By 1974, it was certainly fair to judge that "He is the architect of the modern Soviet Navy and is, by this accomplishment alone, the most distinguished naval officer that Russia, the great landpower, has yet produced." 89

Gorshkov's writings are examined in Chapter 5; he was by any standards one of the more influential analysts and proponents of seapower in the twentieth century - much more so than Tirpitz - and some have compared him to Mahan. ${ }^{90}$ But, for all his theorising, Gorshkov was a pragmatist who selectively used historical experience to advance his policy aims. Like Tirpitz, he was a very skilful operator within his political and bureaucratic environment ${ }^{91}$ and an extremely able administrator. Both enjoyed a long tenure in office, which allowed them to pursue a long-term vision and to plan accordingly, something denied to political and professional leaders in most countries. Both used times of international tension to develop navies designed to exercise influence in peacetime and to fight a maritime opponent in war.

Writing two years after Gorshkov's death, Fleet Admiral Sergeyev credited him with the "colossal service" of taking the Soviet Navy out into the "World Ocean" and putting an end to the "absolute command of the sea" of the western allies. ${ }^{92}$ In 1956, the Soviet Navy was a growing but still coastal force. It had no modern ocean-going ships and, as important, its strategic vision was confined to restricted waters close to the homeland in whose defence it had but a marginal role. Thirty years later, it was an ocean-going navy routinely deployed across the globe able to exercise worldwide influence in peacetime, to defend the country at some distance and dispute the command of the sea of its maritime opponent. It was another remarkable, if tainted, achievement.

\section{Notes}

1 For details of the ships the young Gorshkov served in, see Conway's 1906-1921 p. 309 \& Roger Chesneau (ed.) Conway's All the World's Fighting Ships 1922-1946 London: Conway Maritime Press, 1980 p. 339.

2 Norman Polmar, Thomas A. Brooks \& George E. Fedoroff Admiral Gorshkov: The Man Who Challenged the U.S. Navy Annapolis MD: US Naval Institute Press, 2019 p. 32.

3 Frank Uhlig Forward to Robert W. Herrick Soviet Naval Doctrine and Policy 1956-1986 (3 vols) Lewiston NY: The Edwin Mellen Press, 2003 p. xvii.

4 Geoffrey Till (ed.) Maritime Strategy and the Nuclear Age (2nd ed.) London: Macmillan Press, 1984 p. 68. 
5 Ronald J. Kurth “Gorshkov's Gambit” The Journal of Strategic Studies 28:2 (April 2005) p. 264.

6 John G. Hibbits "Admiral Gorshkov: Architect of the Soviet Navy" in RSRS p. 143.

7 Conway's 1922-1946 pp. 323 \& 326-329.

8 Till p. 68.

9 Hibbits p. 144.

10 Polmar et al. Gorshkov pp. 61-62.

11 Donald W. Mitchell A History of Russian and Soviet Sea Power London: Andre Deutsch, 1974 p. 419.

12 Kevin Rowlands (ed.) 21st Century Gorshkov: The Challenge of Sea Power in the Modern Era Annapolis MD: Naval Institute Press, 2017 p. 14.

13 Sergei Gorshkov "Soviet Seamen in the Battles to Liberate the Danube States" Morskoi Sbornik August 1964, reproduced in Rowlands pp. 16-31.

14 Rowlands p. 23.

15 Rowlands p. 27.

16 Brian Ranft \& Geoffrey Till The Sea in Soviet Strategy London \& Basingstoke: Macmillan, 1983 p. 72.

17 Mitchell p. 518.

18 Peter Tsouras "Soviet Naval Tradition" in Bruce W. Watson \& Susan M. Watson (eds) The Soviet Navy: Strengths and Liabilities Boulder CO: Westview Press, 1986 p. 19.

19 Polmar et al. Gorshkov pp. 72-73.

20 Commander-in-Chief of the Navy from 1946-1947 and again in 1955. He was Minister of the Navy between 1951 and 1955.

21 Admiral Elmo R. Zumwalt "Conclusion" in $R S R S$ p. 146. Admiral Zumwalt was a former USN Chief of Naval Operations.

22 Kurth p. 265.

23 Hibbits p. 144.

24 Conway's 1906-1921 p. 259.

25 Kurth p. 266. Malinovsky was by now First Deputy Minister of Defence.

26 Robert Herrick Soviet Naval Theory and Policy: Gorshkov's Inheritance Annapolis MD: Naval Institute Press, 1989.

27 Three out of four Fleet Commanders were executed.

28 Mitchell p. 374.

29 Gorshkov was among Belli's students before the War.

30 Herrick Gorshkov's Inheritance pp. 258-259.

31 Mitchell p. 374.

32 Including over 250 submarines - a legacy of Young School dominance in the early 1930s.

33 Mitchell p. 468.

34 Class names are NATO designations. For details, see Robert Gardiner (ed.) Conway's All the World's Fighting Ships 1947-1995 London: Conway Maritime Press, 1995 pp. 396-398.

35 Herrick Gorshkov's Inheritance Chapter VI.

36 Zumwalt in RSRS p. 139.

37 Norman Polmar Guide to the Soviet Navy (3rd ed.) Annapolis, MD: Naval Institute Press, 1983 p. 68.

38 Chapter 5.

39 Kurth p. 262.

40 Herrick Doctrine and Policy Book One p. 113.

41 Ibid. p. 110. A similar debate went on in the West, for example in Britain in the late 1950s.

42 Chapter 5.

43 Conway's 1947-1995 p. 379.

44 Herrick Book One p. 115. 
45 TU-16 Badger, TU-95 Bear \& TU-22 Blinder.

46 The highest civilian honour in the Soviet Union, it was frequently awarded to military personnel.

47 Robert W Herrick Soviet Naval Strategy: Fifty Years of Theory and Practice Annapolis MD: US Naval Institute, 1968 p. 73. The ships he saw under construction were probably Kynda-class cruisers and Kashin-class destroyers (NATO names).

48 Herrick Book One p. 97.

49 Evan Mawdsley “The Russian Navy in the Gorshkov Era” in O'Brien (ed.) p. 174.

50 Herrick Book One p. 229.

51 Herrick Book Two p. 563.

52 Michael MccGwire "Advocacy of Seapower in an Internal Debate" in Robert G. Weinland et al. Admiral Gorshkov on "Navies in War and Peace" Center for Naval Analyses, Arlington VA: 1974 p. 38.

53 Intercontinental Ballistic Missiles (ICBMs) were the only ones with the range to reach the United States from the Soviet Union, and vice versa.

54 Ranft \& Till p. 73.

55 Mawdsley p. 171.

56 David Fairhall Russia Looks to the Sea: A study of the expansion of Soviet Maritime Power London: Andre Deutsch, 1971 p. 187.

57 Norman Friedman The Fifty Year War: Conflict and Strategy in the Cold War London: Chatham Publishing, 2000 Chapter 27.

58 Mawdsley p. 174.

59 Sergei Chernyavskii p. 302.

60 Admiral Sergeyev quoted in Herrick Doctrine and Policy Book One p. 352.

61 Kurth p. 268.

62 Mawdsley p. 167.

63 Conway's 1947-1995. The Fleet is examined in more detail in Chapter 7.

64 Norman Polmar Soviet Naval Developments (3rd ed.) Annapolis MD: The Nautical \& Aviation Publishing Company of America, 1983 p. 6.

65 Weinland et al. p. 34.

66 Ibid. p. 35.

67 Herrick Book One p. 98.

68 Mawdsley p. 174.

69 Polmar Soviet Naval Developments p. 25.

70 Ibid. p. 46.

71 Mawdsley p. 175.

72 Polmar Soviet Naval Developments p. 6.

73 German dreadnoughts deployed outside European waters just once, in 1913-1914 when two battleships undertook a flag-showing cruise to West Africa and South America.

74 James M. McConnell "Gorshkov's Doctrine of Coercive Naval Diplomacy in Both Peace and War" in Weinland et al. pp. $71 \& 80$.

75 MccGwire "Advocacy of Seapower" p. 25. Trying to understand the meaning of every nuance of Soviet statements became a feature of "Kremlinology" in the West, sometimes inferring a significance that was entirely circumstantial.

76 Ranft \& Till p. 200.

77 For a Russian view of events in 1973, see Lyle J. Goldstein \& Yuri M. Zhukov "A Tale of Two Fleets: A Russian Perspective on the 1973 Standoff in the Mediterranean" Naval War College Review LVII:2 (Spring 2004) pp. 27-63.

78 Mawdsley p. 171.

79 S. G. Gorshkov The Sea Power of the State Annapolis MD: Naval Institute Press, 1979 (henceforth cited as SPOS).

80 Vertical Take-Off and Landing. The new ships and aircraft are described in more detail in Chapter 7. See also Conway's 1947-1995 pp. 374-376. 
81 Mawdsley p. 177.

82 Polmar Guide to the Soviet Navy p. xi.

83 Chernyavskii p. 304.

84 Now the Russian Navy's only carrier, Admiral Kuznetsov.

85 Kurth p. 262.

86 Robert C. Whitten "Soviet Sea Power in Retrospect: Admiral of the Fleet of the Soviet Union Sergei G. Gorshkov and the Rise and Fall of the Soviet Navy" The Journal of Slavic Military Studies 11:2 (June 1998) p. 77.

87 Chernyavskii p. 281.

88 Quoted in Kurth p. 268.

89 Commander Clyde A. Smith "The Meaning and Significance of the Gorshkov Articles" Naval War College Review XXVII:2 (March/April 1974) p. 18.

90 Zumwalt in RSRS p. 138.

91 Rowlands p. 4.

92 Herrick Book One pp. 328-329. 
those in over-seas trade and sea-power cannot be effected to order, but must proceed organically from the inner development of the nation, and that without a dominating export trade a nation of seventy millions on a confined territory will literally starve. ${ }^{90}$

It is important to understand that Tirpitz was not alone in the views expressed above. His long-term political ally, Bulow, for example, was just as capable of a selective and self-defeating interpretation of German policy:

The fleet that we have built since 1897 and that, though far inferior to England's, has made us the second Sea Power of the world, enables us to support our interests everywhere with all the weight of our reputation as a Great Power. The foremost duty of our navy is to protect our world commerce and the lives and honour of our fellow-countrymen abroad. German battleships have performed this task in the West Indies and the Far East [they had not, though cruisers had]. Emphatically, it is a largely defensive role that we assign to our fleet. It is self-understood that this defensive role might become an offensive one in serious international conflicts. ${ }^{91}$

James Holmes has identified the extent to which Tirpitz was influenced by Mahan. "All of the strands of thought in Mahan's work - geography, commerce, naval strategy, Darwinian struggle - seemed to fuse in Tirpitz's mind, and to command the acquisition of battleships.... Only when the Reich possessed a powerful battlefleet could it expect 'fair play' from Great Britain." 92 Holmes perhaps overlooks the extent to which Tirpitz arrived at similar conclusions before reading Mahan, but he is surely right to point out that not only was Tirpitz's reading of Mahan "thoroughly disfigured"93 but that Mahan's theories were themselves flawed, “... foster[ing] a cleavage between national policy and military strategy ...". ${ }^{94}$ Herwig Holger agrees, arguing that Tirpitz ignored several of Mahan's key tenets such as the need for "ready access to the ocean" while sharing "... several important shortcomings in their naval philosophies". He concludes that "Tirpitz's plan was as much political as it was psychological; it was not strategic. In fact, Tirpitz hardly used the word at all ...".95

\section{Notes}

1 Kelly JMH October 2002 p. 1049.

2 Kelly Tirpitz pp. 36-37. Tirpitz's letter to his parents was dated 11 September 1871.

3 Tirpitz went on to serve in British- and French-built ships.

4 Eventually acquired in 1890 in exchange for Zanzibar. The island of Helgoland dominates the approaches to the Elbe estuary.

5 Construction began in 1887.

6 See Chapter 2.

7 Kelly Tirpitz p. 50.

8 Rolf Hobson Imperialism at Sea: Naval Strategic Thought, The Ideology of Sea Power and the Tirpitz Plan, 1875-1914 Boston MA: Brill Academic Publishers, 2002 p. 194. 
9 Bonker p. 104.

10 See Chapter 2.

11 Kelly Tirpitz p. 77.

12 Germany was arguably not unique in this regard.

13 Quoted in Hobson p. 197.

14 Hobson p. 196. For a useful selection of Mahan's work, see Allan Westcott (ed.) Mahan on Naval Warfare: Selections from the Writings of Rear Admiral Alfred T. Mahan Boston MA: Little, Brown and Company, 1942.

15 Geoffrey Till discusses Mahan's more nuanced view of decisive battle in Seapower: A Guide for the Twenty-First Century London: Frank Cass, 2004 pp. 39-42.

16 Azar Gat A History of Military Thought: From the Enlightenment to the Cold War Oxford: Oxford University Press, 2001 p. 455.

17 See Chapter 2.

18 Hobson pp. 200-201.

19 Bonker Part II.

20 Tactical and Strategic Orders of the Naval Command of the Navy No. IX (henceforth D IX) Berlin: Naval High Command, 16 June 1894. The full text is at Appendix (i), the first time it has been reproduced in full in English.

21 Bonker p. 256.

22 Hobson p. 203.

23 Bonker p. 262.

24 Translation of Tirpitz's late-nineteenth century High German into modern English is a delicate balance. Too literal a translation makes little sense to the modern reader, but too much interpretation of Tirpitz's original meaning can alter the text beyond recognition. The same extract can appear quite differently in separate works.

25 Kelly Tirpitz p. 92.

26 Hobson p. 190.

27 Today this would be expressed as the relationship between "Supported" and "Supporting" Components.

28 Following the loss of Alsace and Lorraine in 1871, France was irreconcilable. A Franco-Russian military convention had been signed two years before $D I X$, which later led to a formal alliance aimed against Germany.

29 Gary E. Weir "Naval Strategy and Industrial Mobilization at the Twelfth Hour: The Sheer Programme of 1918" The Mariner's Mirror 77:3 (August 1991) p. 276. Weir repeats the claim a year later in Building the Kaiser's Navy p. 20.

30 Weir Building the Kaiser's Navy p. 20.

31 Kelly JMH Oct 2002 p. 1059.

32 "High Command of the Navy, Report to the Emperor" in NRS Abyss pp. 15-30.

33 Rear Admiral Tirpitz "Memorandum on the fleet construction programme of the High Command of the Navy" submitted 3 January 1896 NRS Abyss pp. 31-37.

34 A concept dating back to 1690. See Till Seapower pp. 180-186.

35 Chapter 2.

36 Tirpitz to Stosch NRS Abyss pp. 37-41.

37 Kelly Tirpitz p. 116.

38 Park p. 140.

39 Quoted in William Simpson The Second Reich: Germany 1871-1918 Cambridge: Cambridge University Press, 1995 p. 92.

40 NRS Abyss pp. 42-48.

41 Steinberg pp. $129 \& 126$.

42 Kennedy Strategy and Diplomacy p. 133.

43 Foreign Secretary Bulow, speech to the Reichstag 6 December 1897. "We do not want to put anyone into the shadow, but we also demand our place in the sun." James R. Holmes, "Mahan, a 'Place in the Sun' and Germany's Quest for Sea Power" Comparative Strategy 23 (2004) p. 27. 
44 Cited in Herwig Holger "The Failure of German Sea Power: Mahan, Tirpitz and Raeder reconsidered" The International History Review 10:1 (February 1988) p. 78.

45 Weir Building the Kaiser's Fleet p. 21.

46 Jan Ruger The Great Naval Game: Britain and Germany in the Age of Empire Cambridge; Cambridge University Press, 2007 p. 210.

47 Michelle Murray "Identity, Insecurity and Great Power Politics: The Tragedy of German Naval Ambition Before the First World War" Security Studies 19 (2010) p. 680 .

48 NRS Abyss pp. 49-52.

49 Kelly Tirpitz p. 147.

50 NRS Abyss pp. 55-58.

51 Holmes p. 46.

52 Art p. 183.

53 Bonker p. 61.

54 "Amendment to the Act Concerning the German Navy of 10 April 1898, including Justification." 25 January 1900. NRS Abyss pp. 59-80.

55 Kelly Tirpitz p. 199.

56 Bonker p. 139.

57 Paul Kennedy "German Naval Plans Against England" in Paul Kennedy (ed.) The War Plans of the Great Powers 1880-1914 London: Allen \& Unwin, 1979 p. 189.

58 Stephen R. Rock "Risk Theory Reconsidered: American Success and German Failure in the Coercion of Britain, 1890-1914" The Journal of Strategic Studies 11:3 (1988) pp. 343-344.

59 Jonathan Steinberg "The Copenhagen Complex" Journal of Contemporary History 1:3 July 1966 pp. 23-46.

60 Kelly Tirpitz chapter 11.

61 Rear Admiral von Tirpitz to Freiherr von Richthofen, State Secretary of the Foreign Office, 1 November 1904. NRS Abyss pp. 98-100.

62 Tirpitz to Richthofen, 2 December 1904. NRS Abyss p. 101.

63 Tirpitz to Bulow, 18 November 1905. NRS Abyss pp. 176-184.

64 A questionable assertion.

65 Padfield p. 123.

66 Chapter 2.

67 Tirpitz "Memorandum concerning the Significance of the Right of Capture" NRS Abyss pp. 222-226.

68 Tirpitz uses "City of London" as shorthand for British commercial interests.

69 A phrase reminiscent of Napoleon's observation that the English were a "nation of shopkeepers". Dirk Bonker calls it a "fantastical interpretation" (p. 68).

70 Tirpitz "Notes for a Report to the Sovereign, concerning the naval relation to England" 24 October 1910. NRS Abyss pp. 319-320.

71 Kelly Tirpitz p. 309.

72 Tirpitz "Notes for the Report to the Sovereign on the question of future naval policy" NRS Abyss pp. 320-323.

73 Thomas Hoerber "Prevail or Perish: Angle-German naval competition at the beginning of the twentieth century" European Security 20:1 (March 2011) p. 77.

74 Admiral von Holtzendorf "Commander-in-Chief of the High Sea Fleet, Report to the Sovereign" 30 January 2012. NRS Abyss pp. 332-338.

75 Tirpitz "Report to the Sovereign" 2 February 1912. NRS Abyss pp. 338-341.

76 Kennedy War Plans p. 187.

77 NRS Abyss p. 400.

78 Tirpitz "Notes to the Report to the Sovereign" NRS Abyss pp. 411-412.

79 Kelly Tirpitz p. 379.

80 Bonker p. 78.

81 Tirpitz to Muller 25 January 1915 cited in Epkenhans p. 65. 
82 Paul Kennedy "The Development of German Naval Operations Plans against England, 1896-1914" The English Historical Review 89:350 (January 1974) p. 71.

83 For example, on p. 67 of his memoirs Tirpitz claims "The plan of a German battle fleet was evolved without any idea of a war with England".

84 Tirpitz Memoirs Vol. I pp. 58-60.

85 Tirpitz p. 92.

86 Tirpitz p. 151.

87 Admiral Sir John Fisher, First Sea Lord 1904-1910 and 1914-1915.

88 Tirpitz Memoirs p. 197.

89 Tirpitz p. 199.

90 Tirpitz pp. 230-231.

91 Prince Bernhard von Bulow Imperial Germany London: Cassell and Company, 1914 pp. 36-37.

92 Holmes pp. 42-43.

93 Holmes p. 47.

94 Holmes p. 52.

95 Herwig IHR 10:1 pp. $72 \& 80$. 
Gorshkov developed a credible conception of sea control (or "dominance at sea"), which successfully fuses sometimes mutually exclusive concepts of command of the sea and sea denial. He embraced the role of battle and of a Fleet in Being, understood the role of technological developments, argued for an allarms Joint approach and asserted the need for a balanced fleet, the exact composition of which must be tailored to a particular country's circumstances and requirements.

Gorshkov's contribution to seapower thinking is also significant because, perhaps more than any other writer, he fuses military, economic, scientific and political elements into an overarching whole. This may be because in the Soviet Union all were directly controlled instruments of the state, in contrast to liberal trading nations, past and present. ${ }^{101}$

There were things Gorshkov couldn't do. No amount of political advocacy and doctrinal reasoning could overcome geographic reality. Russia was not, is not and cannot be, a maritime state as much as it is a continental state. Its strategic centre of gravity will always lie on the Eurasian landmass, not at sea. But, for the written part of Gorshkov's legacy, that doesn't matter. He has left a model of seapower for continental states and, more than that, a substantial contribution to enduring ideas about the strategic exploitation of the sea.

\section{Notes}

1 Rowlands 21st Century Gorshkov.

2 Herrick Doctrine and Policy Book One p. xiii. Unless otherwise stated, subsequent journal citations are from Robert Herrick's three-volume Soviet Naval Doctrine and Policy 1956-1986.

3 Rear Admiral Gorshkov "Amphibious Landing Operations of the Azov Military Flotilla” Morskoi Sbornik April 1944. Cited in Herrick Gorshkov's Inheritance pp. $149-150$.

4 Not to be confused with Combat Support ("Fires") in land warfare.

5 Natalia Yegorova "Stalin's Conception of Maritime Power: Revelations from the Russian Archives" The Journal of Strategic Studies 28:2 (April 2005) p. 163.

6 Hudson pp. 42-65.

7 Herrick Book One pp. 74 \& 224.

8 Gorshkov "The Development of Soviet Naval Art" Morskoi Sbornik 2 February 1967.

9 Pravda 26 July 1959 p. 93.

10 Izvestiya 19 May 1963.

11 Morskoi Sbornik July 1963.

12 Pravda 26 July 1959.

13 Pravda 26 July 1964.

14 Herrick Book One p. 232.

15 Morskoi Sbornik February 1967.

16 Herrick Book One p. 227.

17 Herrick Book One p. 274.

18 It has a contemporary equivalent known as "Anti-Access, Area Denial" (A2AD).

19 Morskoi Sbornik October 1967.

20 Pravda 28 July 1968.

21 Morskoi Sbornik February 1967. 


\section{Writings}

22 For example, in Krasnaya Zvezda (Red Star) February 1963.

23 Pravda 30 July 1967.

24 Literaturnaya Gazeta May 1965.

25 Morskoi Sbornik February 1967.

26 Pravda 14 February 1968.

27 For example, the US Navy's seminal From the Sea White Paper published in 1992.

28 Voennaya Mysl (Military Thought) January 1968.

29 Morskoi Sbornik February 1967.

30 Future Soviet carriers were to carry their own long-range anti-ship missiles instead of attack aircraft, a marked difference with Western practice.

31 Morskoi Sbornik March 1965.

32 Sea Lines of Communication.

33 Bloknot Agitatora (Agitator) July 1969.

34 The articles and their commentaries were subsequently re-published in book form as Red Star Rising at Sea op. cit.

35 "Navvies in War and Peace" Proceedings 100:1, January 1974.

36 Gray Leverage of Sea Power p. ix.

37 "Russia's Road to the Sea, Peter I to Napoleon" Proceedings 100:2, February 1974.

38 Memorandum dated 3 January 1896 cited in Chapter 4.

39 "The Post-Napoleonic Period to Russo-Japanese War" Proceedings 100:3, March 1974.

40 “The First World War" Proceedings 100:4, April 1974.

41 "The Soviet Navy in the Revolution" Proceedings 100:5, May 1974. Of course, there was no "Soviet Navy" until after the Bolshevik seizure of power.

42 Mitchell p. 343

43 “The Soviet Navy Rebuilds, 1928-41" Proceedings 100:6, June 1974.

44 Chapter 3.

45 The "Old" and "New" schools, respectively.

46 Julian S. Corbett Some Principles of Maritime Strategy with an Introduction and Notes by Eric J. Grove Annapolis MD: Naval Institute Press, 1988 p. 318. Corbett's work was originally published in 1911.

47 “The Second World War" Proceedings 100:7, July 1974.

48 Whitten p. 66.

49 "The Soviet Navy in the Great Patriotic War" Proceedings 100:8, August 1974.

50 "Analysis of Navies in the Second World War" Proceedings 100:9, September 1974.

51 "Navies as Instruments of Peacetime Imperialism" Proceedings 100:10, October 1974.

52 James Cable Gunboat Diplomacy 1919-1991 (3rded) Basingstoke: Macmillan, 1994 p. 14.

53 "Some Problems in Mastering the World Ocean" Proceedings 100:11, November 1974.

54 In the 1970 s there was, for example, much interest in "manganese nodules" apparently littering the sea floor. Resource exploitation played a bigger part in negotiations leading to the 1982 UN Convention on the Law of the Sea (UNCLOS) than might be the case today.

55 Bruce W. Watson "Comments on Gorshkov's 'Sea Power of the State" " US Naval Institute Proceedings 103:4 (April 1977) p. 46.

56 The English translation appeared later, in 1979.

57 David J. Kenney “A primer on S.G. Gorshkov's Sea Power of the State" Naval War College Review XXIX:4 (Spring 1977) p. 94.

58 SPOS pp. ix, 1-2, 58.

59 Mahan The Influence p. 25.

60 SPOS p. 271. 
61 SPOS pp. 130-131, $212 \& 245$.

$62 S P O S$ pp. ix, 5-6 \& 9.

$63 S P O S$ pp. x \& 178. One of many exact repetitions from the earlier articles.

64 SPOS p. 183.

65 SPOS pp. x, 68-69 \& 159.

66 SPOS p. 214.

67 Corbett p. 16.

68 SPOS p. 214.

69 SPOS pp. 216-217.

70 SPOS p. 221.

71 Till Maritime Strategy p. 73.

72 SPOS p. 4.

73 Herrick Book Two p. 592.

74 SPOS p. 277.

75 SPOS pp. 180, 60, 82-83 \& 154-155.

76 SPOS pp. 248-251.

77 Ranft \& Till p. 194

78 Kenneth R. McGruther The Evolving Soviet Navy Newport RI: Naval War College Press, 1978 p. 69.

79 SPOS pp. 247-248.

80 SPOS pp. 66, $153 \& 144$.

81 Kenney p. 97.

82 SPOS Chapter 4. Such is its significance, the chapter is reproduced in full in Kevin Rowland's recent re-interpretation 21st Century Gorshkov op. cit.

83 SPOS p. 213.

84 SPOS p. 222.

85 SPOS pp. 222-234.

86 Footnote 3, above.

87 SPOS p. 284.

88 Rear Admiral Raja Menon Maritime Strategy and Continental Wars London; Frank Cass, 1998 p. 36.

89 Michael MccGwire "Gorshkov's Navy Part II" United States Naval Institute Proceedings 115:9 (September 1989) p. 44.

90 Herrick Book Three p. 1069.

91 Book Three p. 1097.

92 Voyennaya Mysl February 1985.

93 Voyenno-Istoricheskiy Zhurnal July 1985.

94 Morskoi Sbornik May 1984.

95 Morskoi Sbornik April 1985.

96 The book has not been translated in full, but is extensively cited and analysed in Captain Steve F. Kime et al. "Gorshkov's Final Words: What Do They Mean?" USNI Proceedings 115:5 (May 1989) pp. 131-148.

97 Kime p. 132.

98 Captain Larry Seaquist in Kime p. 142.

99 Jessica Huckabey "The Paradox of Admiral Gorshkov" Center for International Maritime Security, 1 October 2015. http://cimsec.org/paradox-admiral-gorshkov/13197

100 Robert B. Bathurst Understanding the Soviet Navy: A Handbook Newport RI: Naval War College Press, 1979 p. 2.

101 I am grateful to Captain Kevin Rowlands RN for emphasizing this point to me. 
The battleships Bismarck and Tirpitz, plus a handful of heavy cruisers and the first of a new fleet of U-Boats, were the early manifestations of Nazi Germany's renewed naval ambitions. More was to follow and, in April 1939, Hitler repudiated a 1935 Anglo-German Naval Agreement to permit a naval programme explicitly aimed at Britain. The new "Z-Plan" would, by 1944, produce a fleet of ten battleships, four aircraft carriers, six battlecruisers and "pocket" battleships and over 250 U-Boats. Two battleships and a single carrier from this programme were laid down but never completed as, just as in the First World War, once war broke out (again, earlier than the Navy hoped) naval construction was focused on submarines.

Tirpitz was therefore the last capital ship completed for the Reichsmarine. The design was a much-updated development of the last dreadnoughts completed by Tirpitz himself, the Badens. The ship Tirpitz was, in programmatic terms, a replacement for the old pre-dreadnought Schleswig-Holstein authorised under Tirpitz's Second Navy Law and commissioned in 1908, the last of the type. ${ }^{55}$ Tirpitz was commissioned on 25 February 1940 and, having completed trials and defect rectification, was operational in September 1941, by which time her sister ship had already been sunk in action.

Tirpitz saw little action other than being the subject of no less than 22 separate air and submarine attacks. But the potential threat this single ship posed to Arctic convoys en route to Russia meant that Tirpitz performed a classic Fleet in Being role, tying down a significant portion of the Royal Navy's large surface ships and disrupting the conduct of convoy operations, most notably the famous PQ-17 convoy in July 1942. The ship was finally sunk in November 1944.

"Tirpitz, which had long haunted enemy strategy on the broad oceans she never sailed, was finally destroyed. Her fate resembles that of the German High Seas Fleet of World War I: both were potent threats contained by the British at great cost." ${ }^{56}$

\section{Notes}

1 Park p. 129.

2 Massie p. 173.

3 For details of the ships Tirpitz inherited, see Conway's 1860-1905 pp. 242-265.

4 Art p. 180.

5 NRS Abyss p. 49.

6 Padfield p. 112.

7 NRS Abyss pp. 59-60.

8 For details of the German pre-dreadnought classes of battleships, see Conway's 1860-1905 pp. 247-249.

9 Lord Selborne "The Navy Estimates and the Chancellor of the Exchequer's Memorandum on the Growth of Expenditure" Abyss pp. 119-120.

10 Hobson p. 252.

11 For details of HMS Dreadnought, see Conway's 1906-1921 pp. 21-22.

12 Norman Friedman Fighting the Great War at Sea: Strategy, Tactics and Technology Barnsley: Seaforth Publishing, 2014 p. 37.

13 Padfield p. 126. 
14 Herwig Luxury Fleet p. 58.

15 Bernard Brodie, quoted in Holger Herwig "The German Reaction to the Dreadnought Revolution" The International History Review (IHR) 13:2 (1991) p. 274.

16 For details of German dreadnoughts, see Conway's 1906-1921 pp. 145-155.

17 As some of his staff advised. Bonker p. 285.

18 Arthur J. Marder From the Dreadnought to Scapa Flow: The Royal Navy in the Fisher Era, 1904-1919. Vol. I The Road to War, 1904-1914 pp. 416-420.

19 Friedman p. 196.

20 Massie p. 496.

21 Friedman p. 198.

22 Conway's 1906-1921 p. 140.

23 Kelly p. 341.

24 NRS Abyss p. 277.

25 Ibid.

26 For an extensive coverage of the options considered by Tirpitz, see Friedman pp. 204-206.

27 Epkenhans p. 53.

28 Art p. 170.

29 Art p. 195.

30 Herwig Luxury Fleet pp. $61 \& 88$.

31 Weir Building the Kaiser's Navy p. 143.

32 Kelly p. 137.

33 Captain L. Persius "How Tirpitz Ruined the German Fleet" translated by Captain Frank C. Bowen RM RUSI Journal 64:3 (August 1919) p. 504.

34 Bonker p. 287.

35 Herwig Luxury Fleet p. 111.

36 Friedman p. 124.

37 Art p. 183.

38 Philip Pugh The Cost of Seapower: The Influence of Money on Naval Affairs from 1815 to the Present Day London: Conway Maritime Press, 1986 p. 169.

39 Herwig Luxury Fleet pp. 44 \& 61.

40 Kelly p. 332 \& Herwig Luxury Fleet Table 7.

41 Imperial Navy Office, Budget Division "Memorandum Concerning the Further Development of the Navy" May 1906 Abyss pp. 198-211.

42 Herwig Luxury Fleet Table 17.

43 Volker R. Berghahn Imperial Germany 1871-1914: Economy, Society, Culture and Politics Providence RI: Berghahn Books, 1994 pp. 330-331.

44 Herwig Luxury Fleet p. 72.

45 Weir Chapter 5.

46 Tirpitz "Notes to the Report to the Sovereign" 17 May 1914 Abyss p. 411.

47 Herwig Luxury Fleet p. 75.

48 Hobson p. 244.

49 Berghahn p. 280.

50 Weir p. 118.

51 Jonathan Steinberg “The Kaiser's Navy and German Society" Past and Present 28, (July 1964) p. 104.

52 Ruger p. 144.

53 Herwig Luxury Fleet p. 256.

54 For details, see Bernard Ireland Jane's Battleships of the 20th Century London: HarperCollins, 1996 pp. 50-51.

55 David Brown Tirpitz: The Floating Fortress London: Arms and Armour Press, 1977 p. 15.

56 Rear Admiral William H. Langenberg "The German Battleship Tirpitz: A Strategic Warship?" Naval War College Review XXXIV: 4 (July-August 1981) p. 90. 
Soviet Union Gorshkov as the city of Baku was now the capital of the newlyindependent republic of Azerbaijan in the Caucasus.

Now operating only helicopters (when she was at sea at all), in 1994 the ship suffered a boiler explosion and was in repair for over a year. The ship was finally retired from Russian service in 1996, less than nine years after being commissioned, and offered for sale. Negotiations with India proceeded fitfully until agreement was reached in 2004. The contract provided for conversion from VTOL to STOBAR configuration, regeneration of the now long-dormant ship and supply of MiG-29 aircraft. ${ }^{71}$ The ship had been built at the Nikolayev yard in Ukraine. By now Ukraine was an independent state, so the rebuilding of Gorshkov, now renamed again as Vikramaditya, was undertaken at the Sevmash shipyard in Severodvinsk in the Russian north. The work transformed the ship from hybrid cruiser/carrier into a pure carrier with a full-length flight deck with a "ski-jump" and eliminating the main missile armament. The ship was originally scheduled for delivery in 2008 but, as the scale of the work required became evident, this was delayed until 2013, amid increases in cost and political controversy in India. ${ }^{72}$ Vikramaditya eventually arrived in India in January 2014, over five years late and costing nearly three times as much as the original contract. The ship suffered another major fire in April 2019.

The name Admiral Gorshkov ${ }^{73}$ is today (2020) carried by a much more modest ship. Gorshkov is lead ship of a new class of 5,400-ton Project 22350 frigates designed at the turn of the century as successors to the Soviet-era Krivaks. Laid down in 2006, Gorshkov took over 12 years to complete due to funding and technical difficulties. ${ }^{74}$ The Gorshkov was heralded by Moscow as marking a renaissance in Russian naval shipbuilding (hence the name), but this new beginning appears to have faltered - and the Gorshkov-class frigates are the largest surface combatants under construction for the Russian Navy. All its larger units, from a single carrier through cruisers to the destroyers, are ageing Cold War-era designs. Unless the Russian Federation manages to recommence building large surface warships, the future Russian fleet will look rather like the pre-Gorshkov Navy - submarines and small, mainly coastal combatants.

It's not quite what Gorshkov had in mind.

\section{Notes}

1 Yegorova p. 158.

2 For example, Soviet fleet auxiliaries were operated as part of the (state-owned) civilian merchant marine.

3 Milan L. Hauner "Stalin's Big-Fleet Program" Naval War College Review LVII: 2, (Spring 2004) p. 88.

4 Yegorova p. 158.

5 Herrick Soviet Naval Strategy p. 35.

6 Ibid. p. 24.

7 Mawdsley p. 165.

8 Conway's 1947-1995 p. 386.

9 SPOS p. 179. 


\section{Fleets}

10 Project numbers are the original Soviet designators. Phonetic names (submarines) and class names beginning with the letter "K" (surface ships) are NATO designators.

11 Herrick Soviet Naval Strategy p. 61.

12 Conway's 1947-1995 pp. 337-425 provides copious detail of Soviet ships completed after the Second World War and during much of the Gorshkov era.

13 Ministry of Shipbuilding figures, cited in Yegorova p. 165.

14 Draft Resolution of the USSR Council of Ministers, 12 September 1951. Cited in Yegorova p. 172.

15 See Chapter 3.

16 Numbers are approximate as exact commissioning dates and operational status are sometimes unknown. Source: Conway's 1922-1946 \& 1947-1995.

17 Chernyavskii p. 290. Similar claims can be made about other navies. For example, the Royal Navy has "lost" many more ships to successive Defence Reviews than to the Argentine air force and navy in 1982.

18 Herrick Soviet Naval Strategy p. 69.

19 SPOS p. 179.

20 What today might be called "sub-strategic".

21 For details, see Ranft \& Till pp. 98-99 and Conways 1947-1995 pp. 388-390.

22 Ranft \& Till p. 95.

23 For details of the Kyndas and Krestas, see Conway's 1947-1995 pp. 380-381.

24 Ranft \& Till p. 145.

25 Conway's 1947-1995 pp. 375-376.

26 They were consistently trimmed bow-down, and a stern flight deck was not the most efficient way to operate more than a dozen helicopters.

27 Watson p. 19.

28 Polmar Guide to the Soviet Navy p. 2. See also Chapter 3.

29 Mawdsley p. 167.

30 Ibid.

31 McGruther p. 31.

32 Not least because a new anti-submarine missile system (SS-N-14) was initially believed to be an anti-ship weapon.

33 MccGwire Proceedings 115:8 p. 47.

34 Conway's 1947-1995 p. 382.

35 For example, the short-notice, "pop-up" nature of the threat meant ships might not have time to go to General Quarters (USN) or Action Stations (RN). Henceforth, ships would be manned and trained to fight with no more than 50 per cent of the crew closed-up. It was also the catalyst for the Royal Navy's adoption of the multi-role Principal Warfare Officer (PWO) system later copied by most Western navies (though not the USN).

36 Ranft \& Till p. 118.

37 Chernyavskii p. 297.

38 Sources: Conway's 1947-1995 \& Fairhall p. 250. Figures are the total inventory, and numbers of the smaller types are approximate. A significant proportion would be in refit or reserve at any one time.

39 Armed with torpedoes only.

40 Source: Conway's 1947-1995.

41 Classified by the Soviets as a "TAKR" - heavy aircraft carrying cruiser. Full details are in Conway's 1947-1995 pp. 374-375.

42 The fourth ship of the class, eventually named Admiral Gorshkov, did not enter service until 1987, 13 years after the first of the class. The Forger was subsonic, single-seat and carried no radar. Its effective radius of action was little more than the 300 miles range of the SS-N-12 missiles.

43 Khrushchev died in 1971.

44 Polmar The Modern Soviet Navy p. 41. 
45 See Chapter 6.

46 Ranft \& Till p. 127.

47 Polmar Guide to the Soviet Navy pp. 79-80.

48 A seventh boat was laid down but never completed.

49 Over 40 knots.

50 Polmar Modern Soviet Navy p. 19.

51 Such as the British County and US Spruance classes.

52 Polmar Guide to the Soviet Navy p. 156.

53 The name Gorshkov was re-allocated to the fourth of the Kiev-class carriers.

54 The SS-N-19 was developed from the SS-N-12.

55 Chernyavskii p. 303. This cosy relationship was an embodiment of what President Eisenhower had pejoratively described in the United States as the "military/industrial complex", to which socialist societies were apparently every bit as susceptible as capitalist states.

56 Called "small ASW ships" or "MPK" by the Soviets.

57 Chapter 3.

58 Short Take-off But Arrested Recovery.

59 Polmar Modern Soviet Navy p. 74. See also Ranft \& Till pp. 114-116.

60 Source: Conway's 1947-1995.

61 Sovremenny \& Udaloy classes.

62 Krivak class.

63 Polmar Guide to the Soviet Navy p. xi.

64 Captain (later Vice Admiral) Arthur K Cebrowski "A Matter of Timing" US Naval Institute Proceedings 115:5 (May 1989) p. 138.

65 Commander Richard T. Ackley "The Soviet Navy's Role in Foreign Policy" Naval War College Review XXIV:9 (May 1972) p. 62.

66 McGruther p. 69.

67 Mawdsley p. 165.

68 Chernyavskii pp. $297 \& 300$.

69 Mawdsley p. 178.

70 The second and third ships were named Minsk and Novorossiysk, respectively. Details of the Kiev class are in Conway's 1947-1995 pp. 374-375.

71 VTOL - Vertical Take-Off and Landing. STOBAR - Short Take-Off But Arrested Recovery.

72 Jane's Defence Weekly 18 October 2017 pp. 25-26.

73 The ship's full name is Admiral of the Fleet of the Soviet Union Gorshkov.

74 www.iiss.org/blogs/military-balance/2018/08/russian-navy-admiral-gorshkov-frigate. Accessed 4 March 2020. 
significant role in ensuring that Germany would fight Britain and that Germany had the wrong fleet with which to do it.

\section{Notes}

1 Holmes p. 37.

2 Tirpitz "Report to the Sovereign" 28 September 1899. NRS Abyss pp. 55-56.

3 Paul Papayoanou "Interdependence, Institutions and the Balance of Power: Britain, Germany and World War I" International Security 20:4 (Spring 1996) pp. 42-76.

4 A point forcefully made by a recent Chinese study of Imperial Germany's rise and fall. Qiyu Xu Fragile Rise: Grand Strategy and the Fate of Imperial Germany, 1871-1914 op. cit.

5 Ibid. p. 157.

6 Epkenhans Tirpitz p. 33.

7 For example, the two Moroccan crises in 1905-1906 and 1911.

8 German external relations in this period are covered in, among a huge literature, Craig Germany 1866-1945, Xu Qiyu Fragile Rise, Kennedy Anglo-German Antagonism, Henry Kissinger Diplomacy New York: Touchstone, 1994 Chapter 7 and Christopher Clark The Sleepwalkers: How Europe Went to War in 1914 London: Penguin, 2013 Part Two.

9 Kelly p. 462.

10 Park p. 133.

11 Murray pp. 665-666 \& 678.

12 Xu p. 198.

13 Cited in Herwig IHR 10:1 p. 80.

14 David Stevenson Armaments and the Coming of War: Europe 1904-1914 Oxford: Oxford University Press, 1996 p. 2 Fig. 1.

15 Ibid. p. 6 Table 4.

16 Padfield p. 234.

17 From 2,298.5 million marks to 4,844.1 million marks in ten years. NRS Abyss p. 155.

18 Herwig Luxury Fleet p. 72.

19 Ibid. p. 61.

20 Murray p. 658.

21 Steinberg Past \& Present 28 p. 1203.

22 Gat p. 358.

23 Herwig Luxury Fleet p. 75.

24 Angus Ross "Nationalism, Geopolitics and Naval Expansion: From the Nineteenth Century to the Rise of China" Naval War College Review 71:4 (Autumn 2018) p. 18.

25 Holger Herwig "Strategic uncertainties of a nation-state: Prussia-Germany, 1871-1918" in Williamson Murray et al. (eds) The Making of Strategy: Rulers, States and War Cambridge; Cambridge University Press, 1994 p. 263.

26 Herwig Luxury Fleet p. 20 \& Gat pp. 359-360.

27 Epkenhans Tirpitz p. 41.

28 Padfield p. 273.

29 NRS Abyss p. 283.

30 Stevenson pp. 7-8 Tables $6 \& 8$.

31 Dennis Showalter "From Deterrent to Doomsday Machine: The German Way of War, 1890-1914" The Journal of Military History 64:3 (July 2000) p. 694.

32 Niall Ferguson The Pity of War London: Allen Lane, 1998 p. 141.

33 Xu p. 225.

34 Padfield p. 345.

35 Chapter 2. 


\section{Consequences}

36 Terence Zuber The Real German War Plan, 1904-1914 Stroud: The History Press, 2011 p. 175.

37 Stevenson Table 8 \& Zuber p. 180.

38 Paul M. Kennedy "Fisher and Tirpitz: Political Admiral in the Age of Imperialism" in Jordan (ed.) Naval Warfare p. 54.

39 Holmes p. 50.

40 Herwig IHR 10:1 p. 82.

41 NRS Abyss p. 104 \& Ruddock F. Mackay "The Admiralty, The German Navy and the Redistribution of the British Fleet, 1904-1905" The Mariner's Mirror 56:3 (1970) pp. 341-346.

42 H. Arnold-Foster "Notes on a Visit to Kiel and Wilhelmshaven" August 1902 in NRS Abyss pp. 132-137.

43 Herwig Luxury Fleet p. 50.

44 Craig p. 331.

45 Persius p. 515.

46 Cited in Kelly p. 202.

47 Vice Admiral Büchsel in 1905, cited in Herwig "German Reaction” p. 281.

48 Kennedy (ed.) War Plans of the Great Powers Chapter 8.

49 Kelly p. 363. Strachan pp. 410-413 contains a good discussion of the German strategic dilemma.

50 Art pp. 196-197.

51 Cited in Marder Dreadnought to Scapa Flow Vol. I p. 431.

52 Padfield p. 80.

53 Holmes p. 46.

54 Rock p. 353.

55 Xu p. 225.

56 Gray Leverage of Seapower p. 201.

57 Cited in Richard Langhorne "The Naval Question in Anglo-German Relations, 1912-1914" The Historical Journal 14:2 (June 1971) p. 361.

58 Cited in Arthur J. Marder British Naval Policy 1880-1905: The Anatomy of British Sea Power London: Putnam \& Company 1940 p. 456.

59 Murray p. 684.

60 Lord Selborne, First Lord of the Admiralty "Naval Policy of Foreign Countries" 16 November 1901 NRS Abyss p. 119.

61 Kennedy Strategy and Diplomacy p. 156.

62 Huw Strachan The First World War London: Oxford University Press, 2003 p. 26.

63 David Stafford "A Moral Tale: Anglo-German Relations, 1860-1914" The International History Review 4:2 (May 1982) p. 253.

64 Sean Lynn-Jones "Détente and Deterrence: Anglo-German Relations, 1911-1914 International Security 11:2, (Fall 1986) pp. 121-150.

65 Maurer "Averting the Great War?" pp. 25-42.

66 Strachan p. 33.

67 A consequence of the German annexation of the French provinces of Alsace and Lorraine in 1871.

68 Steinberg "Copenhagen Complex" p. 31. For a recent and authoritative analysis of European diplomatic crises in the years before 1914, see Clark The Sleepwalkers Part Two.

69 Craig p. 311.

70 Strachan p. 20.

71 Cited in Craig p. 337.

72 The title of Christopher Clark's Sleepwalkers is suggestive of a recent thesis - that no one actively sought a European war but all blundered into it.

73 Hobson p. 56.

74 Tirpitz Vol. I p. 284. 
75 Marder Dreadnought to Scapa Flow Vol. I p. 432.

76 Ibid.

77 The detailed naval history of the First World War is beyond the scope of this work. Among a huge literature, some of the better accounts are Halpern A Naval History of the First World War, Friedman Fighting the Great War at Sea and Robert K. Massie Castles of Steel: Britain, Germany and the Winning of the Great War at Sea London: Jonathan Cape, 2004.

78 Roger Chickering Imperial Germany and the Great War, 1914-1918 Cambridge: Cambridge University Press, 2004 p. 88.

79 Herwig Luxury Fleet p. 149.

80 Padfield p. 343.

81 Strachan pp. 208-215.

82 Herwig Luxury Fleet p. 162.

83 Chapter 6.

84 Herwig Luxury Fleet p. 165.

85 The conduct and outcome of Jutland remain as controversial as the origins of the War. One of the most comprehensive and authoritative analyses seen from the British perspective is Andrew Gordon The Rules of the Game: Jutland and British Naval Command London: John Murray, 1996. Also good is John Campbell Jutland: An Analysis of the Fighting London: Conway, 1986. An authoritative shorter account is in Halpern pp. 310-329.

86 Halpern p. 328.

87 Herwig "Strategic uncertainties" p. 271.

88 Halpern p. 335.

89 Williamson Murray "Naval Power in World War I" in Colin S. Gray \& Roger W. Barnett (eds) Seapower and Strategy Annapolis MD: US Naval Institute Press, 1989 pp. 186-212.

90 Halpern p. 341.

91 Ibid. p. 380.

92 Herwig Luxury Fleet p. 247.

93 Weir "The Scheer Programme of 1918" The Mariner's Mirror 77:3.

94 Even after four and half years fighting on the Western Front, no such mutinies occurred in the Army.

95 Halpern p. 447.

96 Xu p. 201.

97 Hobson pp. 261-262.

98 Persius "How Tirpitz Ruined the German Fleet" op. cit.

99 NRS Abyss p. xxxix.

100 Herwig Luxury Fleet p. 191.

101 Kennedy War Plans of the Great Powers p. 190.

102 Herwig Luxury Fleet p. 208.

103 Epkenhans p. 86.

104 Murray p. 670.

105 Holwig IHR 10:1 p. 83.

106 Art p. 197.

107 Kelly p. 463.

108 Kelly p. 6. 
balance sheet is a positive one. In the space of 30 years, he transformed the Soviet fleet from a coastal defence force of limited reach into an oceanic navy able to seriously challenge a maritime superpower. He also made a major contribution to maritime strategic thought. He was "both a theorist and a realist ...".63 And he did all this in a profoundly continentalist state. Over 30 years after his death, his writings still reward the reader, and today's Russian fleet still includes a few of the big ships that he initiated, including its only aircraft carrier and a giant (but equally ageing) "battlecruiser". Russia retains more of Gorshkov's legacy than did Germany Tirpitz's legacy. But it would be hard to argue that Gorshkov's undoubted achievements actually achieved anything for the state he served. Like Tirpitz before him, he constructed a fleet that was beyond the capacity of the country to support and which could still not overcome the facts of the country's geography. However much either man or either fleet alarmed their respective opponents, they played a weak hand and lost.

\section{Notes}

1 Watson pp. xiii \& 3.

2 Chernyavski p. 305.

3 Norman Friedman Seapower as Strategy: Navies and National Interests Annapolis MD: Naval Institute Press, 2001 p. 207.

4 Michael MccGwire "Naval Power and Soviet Global Strategy" in Steven E. Miller \& Stephen Van Evera (eds) Navakl Strategy and National Security Princeton NJ: Princeton University Press, 1988 p. 166.

5 Barnett "Soviet Maritime Strategy" in Gray \& Barnett (eds) p. 297.

6 Rowlands p. 2.

7 Chernyavskii p. 301.

8 Vladimir Kuzin \& Sergei Chernyavskii "Russian Reactions to Reagan's Maritime Strategy" The Journal of Strategic Studies 28:2 (April 2005) p. 438.

9 Chernyavskii pp. 303-304.

10 Friedman Seapower as Strategy p. 207.

11 Smith "Gorshkov Articles" NWCR XXVI:5 p. 35.

12 Peter Tsouras "Soviet Naval Tradition" in Watson (eds) p. 3.

13 Vice Admiral (and Professor) K. Stalbo in Morskoi Sbornik October 1983. Herrick Book III p. 1015.

14 Kuzin and Chernyavskii put the figure at 17 per cent, but the essential point remains the same.

15 Mawdsley p. 178 \& note 60.

16 Friedman Fifty Year War p. 418.

17 Vladislav M. Zubok A Failed Empire: The Soviet Union in the Cold War from Stalin to Gorbachev Chapel Hill NC: The University of North Carolina Press, 2007 p. 277.

18 Tyrus W. Cobb "The Future of the Soviet Defense Burden: The Political Economy of Contemporary Soviet Security Policy" Naval War College Review XXXIV:4 (JulyAugust 1981) p. 35 \& J. T. Westwood "Soviet Naval Strategy 1968-1978: A Reexamination” US Naval Institute Proceedings 105:5 (May 1978) p. 120.

19 Jonathan Haslam Russia's Cold War New Haven CT: Yale University Press, 2001 p. 357.

20 Cited in Norman Cigar "The Navy's Battle of the Budget: Soviet Style" Naval War College Review XLIII:2 (Spring 1990) p. 9.

21 Cobb p. 31.

22 Ranft \& Till p. 209. 
23 Cited in Cigar p. 7.

24 Aleksandr Prokhanov in Literaturnaya Gazeta 7 September 1983. See also Chernyavskii pp. 305-306.

25 Cigar p. 11.

26 John Lehman Oceans Ventured: Winning the Cold War at Sea New York: Norton \& Co, 2018.

27 Rear Admiral Valentin Kozlov, cited in Cigar p. 11.

28 Rowlands p. 34.

29 Kurth p. 279.

30 Chernyavskii p. 287.

31 Cited in Herrick Book Three p. 874.

32 Herrick Book One p. xiv.

33 Republished as Red Star Rising at Sea.

34 A point eloquently made in Kevin Rowlands's recent re-interpretation of Gorshkov already cited.

35 Chief of Naval Operations 1970-1974.

36 Admiral Elmo Zumwalt "Introduction", $R S R S$.

37 Rear Admiral E. M. Miller "Commentary" RSRS p. 22.

38 Smith NWCR XXVI:5 p. 20.

39 Michael MccGwire "The Background to Soviet Naval Developments" The World Today 27:3 (March 1971) p. 103.

40 Geoffrey Till "The Soviet Navy after Gorshkov" RUSI Journal 128:4 (December 1983) pp. 62-64.

41 Geoffrey Till "Present and Future Roles of the Soviet Navy" RUSI \& Brassey's Defence Yearbook 1990 London: Brassey's, 1990 p. 282.

42 K. M. Grorgiev \& M. O. Kolosov "Soviet-U.S. Relations at a New State", cited in Cobb p. 44.

43 Zumwalt, Introduction to RSRS.

44 McGruther pp. 66-67.

45 Chernyavskii p. 299.

46 Especially the Delta IV and Typhoon SSBN classes.

47 Herrick Book Three pp. 1228-1229.

48 Till in Brassey's Yearbook 1990 p. 278.

49 Herrick Book Three p. 1122.

50 Till in Brassey's Defence Yearbook 1990 p. 274.

51 Lehman p. 53.

52 Ranft \& Till pp. 181-182.

53 McGruther p. 72.

54 For a recent and authoritative, but necessarily partial, account see John Lehman's Oceans Ventured. Lehman was Reagan's Secretary of the Navy between 1981 and 1987.

55 David A. Rosenburg “'It is Hardly Possible to Imagine Anything Worse': Soviet Thoughts on the Maritime Strategy" Naval War College Review XLI:3 (Summer 1988) pp. 69-105.

56 James Westwood "Soviet Reaction to the U.S. Maritime Strategy" Naval War College Review XLI:3 (Spring 1988) p. 63.

57 Captain Larry Seaquist USN "Hull Down on the Red Horizon" US Naval Institute Proceedings 115:5 (May 1989) p. 147.

58 Kuzin \& Chernyavskii p. 438.

59 Haslam p. 398 \& Rowlands p. 151.

60 Mawdsley p. 178.

61 Hauner p. 116.

62 Mawdsley p. 165.

63 Polmar et al. Gorshkov p. 203. 
China is not the only emergent continental/maritime hybrid. If "Mahan is alive and well and living in Beijing", ${ }^{61}$ he is also spending time in New Delhi. China has commissioned an ex-Soviet aircraft carrier; so has India, the ship previously called Admiral Gorshkov. ${ }^{62}$ India, too, has continental scale and strategically significant land borders - with Pakistan in the northwest and China in the northeast. It also has a huge coastline (larger in relation to its landmass than China) ${ }^{63}$ and, unlike China, its free access to the high seas is not limited by anything like the "First Island Chain". ${ }^{64}$ Its economy, if not on the same scale as China's, is still among the ten largest in the world and likely to move up the rankings. And it is a functioning democracy, the world's largest. Geography and politics may therefore combine to give India even more of a nascent maritime identity than China.

In the middle years of this century, we may therefore come to see not just one but three continental-scale maritime powers. If China and India can both keep their landward distractions within manageable bounds and avoid the policy drift characteristic of Wilhelmine Germany, that could be of profound strategic consequence, especially in terms of their relationships with each other and with the United States. If they heed the German and Russian experiences, both will need to avoid, not just Thucydides's Trap, but also Tirpitz's Trap.

\section{Notes}

1 For example, a section in Robert Whitten's 1998 article in the Journal of Slavic Military Studies on pp. 74-77 refers to "parallel paths".

2 Herrick Book One p. xx.

3 See Menon Maritime Strategy and Continental Wars and Xu Fragile Rise.

4 Clyde A. Smith "Constraints of Naval Geography on Soviet Naval Power" Naval War College Review XXVII:5 (September-October 1974) p. 48.

5 RSRS p. 12.

6 Morskoi Sbornik 1973. Cited in Smith NWCR XXVI:5 p. 30.

7 Gray Leverage of Seapower p. 266.

8 Friedman Seapower as Strategy pp. 206-207.

9 Gray Leverage of Seapower p. 279.

10 Gorshkov's successful wartime command was largely a shore-based one and focused on combined-arms operations against and along the shore and up rivers.

$11 \mathrm{https}: / /$ morethannelson.com/officer/charles-middleton-1st-lord-barham/. Accessed 2 March 2020. Barham, who died in 1813, was a leading advocate of the abolition of the slave trade.

12 Kurth p. 266.

13 Kelly p. 466.

14 MccGuire Proceedings 115:8 p. 51.

15 Murray p. 671 \& Charles L. Glaser "When Are Arms Races Dangerous? Rational versus Suboptimal Arming” International Security 28:4 (Spring 2004) pp. 44-84.

16 Cigar p. 11.

17 Steven Miller "Assessing the Soviet Navy" Naval War College Review XXXII:6 (September-October 1979) p. 64.

18 Strachan p. 34.

19 Hobson p. 42.

20 Glaser p. 52. 


\section{Conclusions}

21 Chapter 8 footnote 71.

22 Lehman Chapter 6.

23 Glaser p. 81.

24 MccGuire "Naval Power and Soviet Global Strategy" p. 134.

25 John J. Mearsheimer The Tragedy of Great Power Politics New York: Norton \& Company, 2001 p. 114.

26 Bonker p. 61.

27 Gray \& Barnett p. 351.

28 Admiral Zumwalt "Conclusion" in RSRS p. 141.

29 Andrew Lambert Seapower States: Maritime Culture, Continental Empires and the Conflict That Made the Modern World New Haven CT: Yale University Press, 2018 p. 313.

30 SPOS p. 254.

31 With the caveat that in the nuclear age the continental United States was vulnerable to long-range strike from both land and sea.

32 Murray p. 669.

33 Lambert p. 327.

34 Arguably it should be five prior to 1914 - France had a much bigger overseas empire than Germany, was a significant naval power in its own right and had a formidable army in Europe.

35 Holmes "Mahan, a 'Place in the Sun"” p. 41.

36 Ross p. 37.

37 SPOS p. 83.

38 Vice Admiral Turner, commentary on "Some Problems in Mastering the World Oceans" RSRS p. 135.

39 Chernyavskii p. 287.

40 This point is argued at length by Dirk Bonker Militarism in a Global Age and Rolf Hobson Imperialism at Sea.

41 Polmar et al. Gorshkov pp. 170-171.

42 Mahan p. 65.

43 Cited in Cigar p. 12.

44 Cited in Herwig Luxury Fleet p. 92.

45 Ferguson The Pity of War p. 85.

46 SPOS p. 154.

47 Bulow p. 46.

48 James Cable The Political Influence of Naval Force in History Basingstoke: Macmillan, 1998 p. 110 \& C. G. Jacobsen "Soviet Strategy: The Naval Dimension" Naval War College Review XXXX:2 Spring 1987 p. 17.

49 Gray \& Barnett p. xii.

50 Colin Gray is eloquent on this point. See Gray \& Barnett Chapter 1 and Gray Leverage of Seapower.

51 Cited in Commander Robert B. Rogers "Trends in Soviet Naval Strategy" Naval War College Review XXI:2 (February 1969) p. 25.

52 Lambert p. 321.

53 Lambert p. 333.

54 Russia's long but ice-bound northern coast means the country remains, in strategic terms, largely land-locked.

55 For a much fuller discussion of this point, see Jack Levy \& William Thompson "Balancing on Land and at Sea" International Security 35:1 (Summer 2010) pp. 7-43.

56 Gray Leverage of Seapower p. 79.

$57 \mathrm{Xu}$ Fragile Rise, especially Chapters Six to Nine.

58 Graham Allison Destined for War: Can America and China Escape Thucydides's Trap? Boston MA: Houghton Mifflin Harcourt, 2017. Revealingly, Allison wrote the Forward to the English translation of Xu's work. The term Thucydides's Trap refers 
to the apocryphal observation of the Peloponnesian War: "It was the rise of Athens and the fear that this instilled in Sparta that made war inevitable."

59 Ross p. 32.

60 Robert D. Kaplan The Revenge of Geography: What the Map Tells us about Coming Conflicts and the Battle Against Fate New York: Random House, 2012 pp. 110 \& 199.

61 Holmes p. 53.

62 Chapter 7.

63 https://en.wikipedia.org/wiki/List_of_countries_by_length_of_coastline. Accessed 24 April 2019.

64 Kaplan p. 214. 


\section{Appendices}

quality ships, manned by more highly trained personnel and employing tactics which were new for that time. The main result of the victory achieved in the naval engagement was that the home country and the British colonies became practically invulnerable to attacks from the direction of the sea. England was able to deprive the enemy of the weapon which was most dangerous for her the navy. Only a navy at that time could directly threaten the home country and the security of the communications connecting England with the colonies which supplied the raw materials for her industry and food products for the population. The liquidation of the threat from the sea freed the hands of the English bourgeoisie to organise and finance new alliances to continue the struggle with Napoleonic France. France, however, was forced to refrain once and for all from combat operations at sea and to seek other ways not connected with the sea to combat her main enemy.

Thus, the course of the war at sea and the gaining of domination by the English Nay had a great effect on the further policy of the belligerents.

From all that has been said, it follows that from the dawning of the capitalist era, the navies of the Western states have represented not only a part of the armed forces, which were employed in war in the naval theatres, but also a weapon of state policy in peacetime, which permitted them to enslave underdeveloped peoples and countries overseas and to transform them into their own colonies. The fleets of the Western European powers travelled the path from 'privateers in the service of the King' to regular naval forces which received an organised structure and official operational tactics. The employment of this naval force in wars, especially when it was the main force in achieving the goals of the war, had a considerable influence on state policy, which was determined and conducted taking into account the disposition of the forces at sea at certain times.

Maritime states having great economic capabilities have wisely used their naval forces in peacetime to put pressure on their enemies, as a type of military demonstration, as threats of interrupting sea communications and as a hindrance to ocean commerce.

Navies have served these states as an important means of further enrichment and of extending expansion and colonisation.

In addition, navies have also carried out the pleasant mission of being discoverers. Naval ships of the great powers, including Russia, have carried out wide-scale oceanographic studies and made an inestimable contribution to the science of geography. This tradition of mariners (including also naval mariners) still continues even today, when the 'blank spots' in the ocean are becoming fewer and fewer, yet the knowledge of the secrets of the ocean represents a very great scientific task even today.

\section{Notes}

1 Karl Marx Kapital Vol. 1 p. 754.

2 Karl Marx Kapital Vol. 3 p. 345.

3 Fyffe's History of Modern Europe Vol. 1 p. 281. 


\section{Bibliography}

\section{(i) Tirpitz}

Art, Robert J. "The Influence of Foreign Policy on Seapower: New Weapons and Weltpolitik in Wilhelmine Germany" in Robert J. Art and Kenneth N. Waltz (eds) The Use of Force: International politics and Foreign Policy (2nd ed.) Lanham MD: University Press of America, 1983

Berghahn, Volker R. Imperial Germany 1871-1914: Economy, Society, Culture and Politics Providence Providence RI: Berghahn Books, 1994

Bird, Keith, "The Tirpitz Legacy: The Political Ideology of German Sea Power" The Journal of Military History 69:3 (July 2005) pp. 821-826

Bonker, Dirk, Militarism in a Global Age: Naval Ambitions in Germany and the United States Before World War I Ithaca: Cornell University Press, 2012

Brown, David, Tirpitz: The Floating Fortress London: Arms \& Armour Press, 1977

Bulow, Prince Bernhard von, Imperial Germany London: Cassell \& Co, 1914

Chesneau, Roger \& Kolesnik (eds) Conway's All the World's Fighting Ships 1860-1905 London: Conway Maritime Press, 1979

Chickering, Roger, Imperial Germany and the Great War, 1914-1918 (2nd ed.) Cambridge: Cambridge University Press, 2004

Clark, Christopher, Kaiser Wilhelm II: A Life in Power London: Penguin Books, 2009

Clark, Christopher, The Sleepwalkers: How Europe Went to War in 1914 London: Penguin Books, 2013

Craig, Gordon A. Germany 1866-1945 Oxford: Oxford University Press, 1981

Earle, Edward Mead (ed), Makers of Modern Strategy: Military Thought from Machiavelli to Hitler Princeton: Princeton University Press, 1971

Epkenhans, Michael, Tirpitz: Architect of the German High Seas Fleet Washington, DC: Potomac Books, 2008

Epkenhans, Michael, "Bismarck, Wilhelm II and German Military Leadership" Journal of Military and Strategic Studies 13:1 (Fall 2010) pp. 42-60

Ferguson, Niall, "The Kaiser's European Union: What if Britain had 'stood aside' in August 1914?" in Niall Ferguson (ed.) Virtual History: Alternatives and Counterfactuals London: Papermac, 1997

Ferguson, Niall, The Pity of War London: Allen Lane, 1998

Friedman, Norman, Fighting the Great War at Sea: Strategy, Tactics and Technology Barnsley: Seaforth Publishing, 2014

Gordon, Andrew The Rules of the Game: Jutland and British Naval Command London: John Murray, 1996 


\section{Bibliography}

Gray, Randal (ed.) Conway's All the World's Fighting Ships 1906-1921 London: Conway Maritime Press, 1985

Halpern, Paul G. A Naval History of World War I Annapolis MD: Naval Institute Press, 1994

Herwig, Holger H. 'Luxury Fleet': The Imperial German Navy 1888-1918 London: George Allen \& Unwin, 1980

Herwig, Holger H. "From Tirpitz Plan to Schlieffen Plan: Some Observations on German Military Planning” Journal of Strategic Studies 9:1 (March 1986) pp. 53-63

Herwig, Holger H. "The Failure of German Sea Power, 1914-1945: Mahan, Tirpitz and Raeder Reconsidered" The International History Review 10:1 (February 1988) pp. $68-105$

Herwig, Holger H. "The German Reaction to the Dreadnought Revolution" The International History Review 13:2 (May 1991) pp. 273-283

Herwig, Holger H. "Strategic uncertainties of a nation-state: Prussia-Germany, 1871-1918" in Williamson Murray et al. (eds) The Making of Strategy: Rulers, States and War Cambridge: Cambridge University Press, 1994 pp. 242-277

Herwig, Holger H. "Germany and the 'Short-War' Illusion: Toward a New Interpretation" The Journal of Military History 66:3 (July 2002) pp. 681-694

Hobson, Rolf, Imperialism at Sea: Naval Strategic Thought, the Ideology of Sea Power and the Tirpitz Plan, 1875-1914 Boston MA: Brill Academic Publishers, 2002

Hoerber, Thomas, "Prevail or Perish: Anglo-German naval competition at the beginning of the twentieth century" European Security 20:1 (March 2011) pp. 65-79

Holmes, James R., "Mahan, a 'Place in the Sun' and Germany's Quest for Sea Power" Comparative Strategy 23 (2004) pp. 27-61

Jordan, Gerald (ed.) Naval Warfare in the Twentieth Century 1900-1945 London: Croom Helm, 1977

Kelly, Patrick J. Tirpitz and the Imperial German Navy Bloomington IN: Indiana University Press, 2011

Kelly, Patrick J. "Strategy, Tactics and Turf Wars: Tirpitz and the Oberkommando der Marine, 1892-1895" The Journal of Military History 66:4 (October 2002) pp. 1033-1060

Kennedy, Ludovic, Menace: The Life \& Death of the Tirpitz London: Sidgwick \& Jackson, 1979

Kennedy, Paul, "The Development of German Naval Operations Plans Against England, 1896-1914" The English Historical Review 89:350 (January 1974) pp. 48-76

Kennedy, Paul, The Rise of the Anglo-German Antagonism, 1860-1914 London: Allen \& Unwin, 1982

Kennedy, Paul, Strategy and Diplomacy 1870-1945 London: Fontana Books, 1983

Kennedy, Paul (ed.) The War Plans of the Great Powers London: Allen \& Unwin, 1979

Lambi, Ivo N. The Navy and German Power Politics 1862-1914 Boston MA: Allen \& Unwin, 1984

Langenburg, William, “The German Battleship Tirpitz: A Strategic Warship?” Naval War College Review XXXIV:4 (July-August 1981) pp. 81-92

Langhorne, Richard, "The Naval Question in Anglo-German Relations, 1912-1914" The Historical Journal 14:2 (June 1971) pp. 359-370

Lee, Stephen J. Imperial Germany 1871-1918 London: Routledge, 1999

Lynn-Jones, Sean, "Détente and Deterrence: Anglo-German Relations, 1911-1914 International Security 11:2 (Fall 1986) pp. 121-150

Mackay, Ruddock F. "The Admiralty, The German Navy and the Redistribution of the British Fleet, 1904-1905” The Mariner's Mirror 56:3 (1970) pp. 341-346 
Marder, Arthur J. British Naval Policy 1880-1905: The Anatomy of British Sea Power London: Putnam \& Co, 1940

Marder, Arthur J. From the Dreadnought to Scapa Flow: The Royal Navy in the Fisher Era, 1904-1919 Vol. I The Road to War, 1904-1914 London: Oxford University Press, 1961

Massie, Robert K. Dreadnought: Britain, Germany and the Coming of the Great War New York: Random House, 1991

Massie, Robert K. Castles of Steel: Britain, Germany and the Winning of the Great War at Sea London: Jonathan Cape, 2004

Maurer, John H. "Averting the Great War?: Churchill's Naval Holiday" Naval War College Review 67:3 (Summer 2014) pp. 25-42

Murray, Michelle, "Identity, Insecurity and Great Power Politics: The Tragedy of German Naval Ambition Before the First World War" Security Studies 19 (2010) pp. 656-688

Padfield, Peter, The Great Naval Race: Angle-German Naval Rivalry 1900-1914 St Albans: Granada, 1974

Papayoanou, Paul, "Interdependence, Institutions and the Balance of Power: Britain, Germany and Word War I" International Security 20:4 (Spring 1996) pp. 42-76

Park, Evan, "The Nationalist Fleet: Radical Nationalism and The Imperial German Navy from Unification to 1914" Journal of Military and Strategic Studies 16:2 (2015) pp. 125-159

Persius, Captain L. "How Tirpitz Ruined the German Fleet" RUSI Journal 64:3 (August 1919) pp. 502-516

Porter, Ian \& Armour, Ian D. Imperial Germany 1890-1918 London: Longman, 1991

Rahn, Werner, "German Navies from 1848 to 2016" Naval war College Review 70:4 (Autumn 2017) pp. 13-47

Rock, Stephen, "Risk Theory Reconsidered: American Success and German Failure in the Coercion of Britain, 1890-1914 Journal of Strategic Studies 11:3 (1988) pp. 342-364

Rohl, J. C. G. "Admiral von Muller and the Approach of War, 1922-1914" The Historical Journal XII:4 (1969) pp. 651-673

Rosenburg, Arthur, Imperial Germany New York: Oxford University Press, 1931

Ruger, Jan, The Great Naval Game: Britain and Germany in the Age of Empire Cambridge: Cambridge University Press, 2007

Seligmann, Matthew, Naval Intelligence from Germany: The Reports of the British Naval Attaches in Berlin, 1906-1914 Farnham: Ashgate for the Navy Records Society, 2007

Seligmann, Matthew et al. (eds), The Naval Route to the Abyss: The Anglo-German Naval Race 1895-1914 Farnham: Ashgate for the Navy Records Society, 2015

Showalter, Dennis, "From Deterrent to Doomsday Machine: The German Way of War, 1890-1914" The Journal of Military History 64:3 (July 2000) pp. 679-710

Simpson, William, The Second Reich: Germany 1871-1918 Cambridge: Cambridge University Press, 1995

Stafford, David, "A Moral Tale: Anglo-German Relations, 1860-1914” The International History Review 4:2 (May 1982) pp. 249-263

Steinberg, Jonathan, "The Kaiser's Navy and German Society" Past and Present 28 (July 1964) pp. 102-110

Steinberg, Jonathan, Yesterday's Deterrent: Tirpitz and the Birth of the German Battle Fleet London: Macdonald, 1965

Steinberg, Jonathan, "The Copenhagen Complex" Journal of Contemporary History 1:3 (July 1966) pp. 23-46 


\section{Bibliography}

Stevenson, David, Armaments and the Coming of War: Europe 1904-1914 Oxford: Oxford University Press, 1996

Strachan, Hew, The First World War Vol. I To Arms Oxford: Oxford University Press, 2001

Von Tirpitz, Alfred, My Memoirs Vols I \& II London: Hurst \& Blackett, 1919

Weir, Gary E. "Naval Strategy and Industrial Mobilization at the Twelfth Hour: The Sheer programme of 1918" The Mariner's Mirror 77:3 (August 1991) pp. 275-287

Weir, Gary E. Building the Kaiser's Navy: The Imperial Naval Office and German Industry in the von Tirpitz Era, 1890-1919 Annapolis MD: Naval Institute Press, 1992

$\mathrm{Xu}$, Qiyu, Fragile Rise: Grand Strategy and the Fate of Imperial Germany, 1871-1914 Cambridge MA: The MIT Press, 2017

Zuber, Terence, Inventing the Schlieffen Plan: German War Planning 1871-1914 Oxford: Oxford University Press, 2002

Zuber, Terence, The Real German War Plan, 1904-14 Stroud: The History Press, 2011

\section{(ii) Gorshkov}

Ackley, Richard T. "The Soviet Navy's Role in Foreign Policy” Naval War College Review XXIV:9 (May 1972) pp. 48-65

Baldwin, Hanson W. "The Soviet Navy” Foreign Affairs 33:4 (July 1955) pp. 587-604

Bathurst, Robert B. Understanding the Soviet Navy: A Handbook Newport RI: Naval War College Press, 1979

Breemer, J. S. "Rethinking the Soviet Navy" Naval War College Review XXXIV:1 (January-February 1981) pp. 4-12

Bringle, W. F. "The Challenge Posed by the Soviet Navy" RUSI Journal 118:2 (June 1973) pp. 11-16

Cebrowski, Captain (later Vice Admiral) Arthur K. "A Matter of Timing" US Naval Institute Proceedings 115:5 (May 1989)

Chernyavskii, Sergei, "The Era of Gorshkov: Triumph and Contradictions" The Journal of Strategic Studies 28:2 (April 2005) pp. 281-308

Chesneau, Roger (ed.) Conway's All the World's Fighting Ships 1922-1946 London: Conway Maritime Press, 1980

Cigar, Norman, “The Navy's Battle of the Budget: Soviet Style" Naval War College Review XLIII:2 (Spring 1990) pp. 6-30

Cobb, Tyrus W. "The Future of the Soviet Defense Burden: The Political Economy of Contemporary Soviet Security Policy" Naval War College Review XXXIV:4 (July-August 1981) pp. 30-52

Cox, David R. "Sea Power and Soviet Foreign Policy" US Naval Institute Proceedings 95:6 (June 1969) pp. 32-44

Cramer, Michael W. Admiral of the Fleet of the Soviet Union Sergei G. Gorshkov: An Operational Code and Thematic Analysis Monterey CA: Naval Postgraduate School, 1975

Edmonds, Martin \& Skitt, John, "Current Soviet Maritime Strategy and NATO" International Affairs 45:1 (January 1969) pp. 28-43

Fairhall, David, Russia Looks to the Sea: A Study of the Expansion of Soviet Maritime Power London: Andre Deutsch, 1971

Friedman, Norman, The Fifty Year War: Conflict and Strategy in the Cold War London: Chatham Publishing, 2000

Gardiner, R (ed.) Conway's All the World's Fighting Ships 1947-1995 London: Conway Maritime Press, 1995 
Goldstein, Lyle J. \& Zhukov, Yuri M, "A Tale of Two Fleets: A Russian Perspective on the 1973 Standoff in the Mediterranean" Naval War College Review LVII:2 (Spring 2004) pp. 27-63.

Gorshkov, S. G. "The Development of Soviet Naval Science" (excerpts) Naval War College Review XXI:11 (February 1969) pp. 30-42

Gorshkov, S. G. Red Star Rising at Sea Annapolis MD: Naval Institute Press, 1974

Gorshkov, S. G. "Navies in War and in Peace" (11 articles) US Naval Institute Proceedings 100:1-11 (January-November 1974)

Gorshkov, S. G. The Sea Power of the State Annapolis MD: Naval Institute Press, 1979

Haslam, Jonathan, Russia's Cold War New Haven: Yale University Press, 2011

Hauner, Milan L. "Stalin's Big-Fleet Program" Naval War College Review LVII: 2 (Spring 2004) pp. 87-120

Herrick, Robert W. Soviet Naval Strategy: Fifty Years of Theory and Practice MD: Naval Institute Press, 1968

Herrick, Robert W. Soviet Naval Theory and Policy: Gorshkov's Inheritance Annapolis MD: Naval Institute Press, 1989

Herrick, Robert W. Soviet Naval Doctrine and Policy 1956-1986 Books 1-3 Lewiston NY: The Edwin Mellen Press, 2003

Huckabey, Jessica, "The Paradox of Admiral Gorshkov" Center for International Maritime Security, 1 October 2015 http://cimsec.org/paradox-admiral-gorshkov/13197

Hudson, George E. "Soviet Naval Doctrine under Lenin and Stalin" Soviet Studies 28:1 (January 1976) pp. 42-65

Jacobsen, C. G. "Soviet Strategy: The Naval Dimension" Naval War College Review XXXX:2 (Spring 1987) pp. 17-27

Kenney, David J. "A Primer on S.G. Gorshkov's Sea Power of the State" Naval War College Review XXIX: 4 (Spring 1977) pp. 94-104

Kime, Steve F. et al. "Gorshkov's Final Words: What Do They Mean?" US Naval Institute Proceedings 115:5 (May 1989) pp. 131-148

Kurman, Michael \& Polmar, Norman, "New Russian Navy Parts 1 \& 2" USNI Proceedings 142/12 \& 143/1 (December 2016) pp. 66-67 \& (January 2017) pp. 66-67

Kurth, Ronald J. “Gorshkov's Gambit” The Journal of Strategic Studies 28:2 (April 2005) pp. 261-280

Kuzin, Vladimir \& Chernyavskii, Sergei, "Russian Reactions to Reagan's 'Maritime Strategy" “ The Journal of Strategic Studies 28:2 (April 2005) pp. 429-439

Lehman, John, Oceans Ventured: Winning the Cold War at Sea New York: Norton \& Co, 2018

McGruther, Kenneth, The Evolving Soviet Navy Newport RI: Naval War College Press, 1978

MccGuire, Michael, "The Background to Soviet Naval Developments" The World Today 27:3 (March 1971) pp. 93-103

MccGuire, Michael, "Naval Power and Soviet Global Strategy" International Security 3:4 (Spring 1979) pp. 134-189

MccGuire, Michael, "A New Trend in Soviet Naval Developments" Naval War College Review XXXIII:4 (July-August 1980) pp. 3-12

MccGuire, Michael, "Naval Power and Soviet Global Strategy" E. Miller \& Steven Van Evera (eds) Naval Strategy and National Security Princeton NY: Princeton University Press, 1988 pp. 115-170

MccGuire, Michael, "Gorshkov's Navy" (2 parts) US Naval Institute Proceedings 115: 8 \& 9 (August \& September 1989) pp. 44-51 \& 42-47 
Menon, Raja, Maritime Strategy and Continental Wars London: Frank Cass, 1998

Miller, Chris, The Struggle to Save the Soviet Economy: Mikhail Gorbachev and the Collapse of the USSR Chapel Hill: University of North Carolina Press, 2016

Miller, Steven E. "Assessing the Soviet Navy" Naval War College Review XXXII:6 (September-October 1979) pp. 56-66

Mitchell, Donald W. A History of Russian and Soviet Sea Power London: Andre Deutsch, 1974

Moore, John E. The Soviet Navy Today London: Macdonald and Jane's, 1975

Polmar, Norman (ed.) The Modern Soviet Navy London: Arms \& Armour Press, 1979

Polmar, Norman, Guide to the Soviet Navy 3rd ed. Annapolis MD: Naval Institute Press, 1983

Polmar, Norman, Soviet Naval Developments 3rd ed. Annapolis MD: The Nautical \& Aviation Publishing Company of America, 1983

Polmar, Norman et al. Chronology of the Cold War at Sea 1945-1991 Annapolis MD: Naval Institute Press, 1998

Polmar, Norman, Brooks, Thomas \& Fedoroff, George, Admiral Gorshkov: The Man Who Challenged the U.S. Navy Annapolis MD: Naval Institute Press, 2019

Ranft, Bryan \& Till, Geoffrey, The Sea in Soviet Strategy London \& Basingstoke: Macmillan, 1983

Rogers, Robert B. "Trends in Soviet Naval Strategy" Naval War College Review XXI:2 (February 1969) pp. 13-29

Rohwer. Jurgen, "Admiral Gorshkov and the Influence of History Upon Sea Power" US Naval Institute Proceedings 107:5 (May 1981) pp. 150-161

Rosenburg, David A. “'It is Hardly Possible to Imagine Anything Worse': Soviet Thoughts on the Maritime Strategy" Naval War College Review XLI:3 (Summer 1988) pp. 69-105

Rowlands, Kevin (ed.) 21st Century Gorshkov: The Challenge of Sea Power in the Modern Era Annapolis MD: Naval Institute Press, 2017

Seaquist, Captain Larry USN "Hull Down on the Red Horizon" US Naval Institute Proceedings 115:5 (May 1989)

Smith, Clyde A. "The Meaning and Significance of the Gorshkov Articles" Naval War College Review XXVII:2 (March-April 1974) pp. 18-37

Smith, Clyde A. "Constraints of Naval Geography on Soviet Naval Power" Naval War College Review XXVII:5 (September-October 1974) pp. 46-57.

Smith, Myron J. The Soviet Navy 1941-78: A Guide to Sources in English Santa Barbara CA: ABC-Clio, 1980

Suggs, Robert C. "The Soviet Navy: Changing of the Guard?" US Naval Institute Proceedings 108:4 (April 1983) pp. 36-42

Till, Geoffrey, Maritime Strategy and the Nuclear Age (2nd ed.) London: Macmillan, 1984

Till, Geoffrey, "The Soviet Navy after Gorshkov" RUSI Journal 128:4 (December 1983) pp. 62-64

Till, Geoffrey, "Present and Future Roles of the Soviet Navy" RUSI \& Brassey's Defence Yearbook 1990 London: Brassey’s, 1990 pp. 269-292

Vigor, P. H. "Admiral S. G. Gorshkov's Views on Seapower" RUSI Journal 119:1 (March 1974) pp. 53-60

Watson, Bruce W. "Comments on Gorshkov's 'Sea Power of the State" US Naval Institute Proceedings 103:4 (April 1977) pp. 41-47

Watson, Bruce W \& Susan M. (eds) The Soviet Navy: Strengths and Liabilities Boulder CO: Westview Press 1986 
Weinland, Robert G. et al. "Admiral Gorshkov's 'Navies in War and Peace' "Survival 17:2 (1975) pp. 54-63

Weinland, Robert G, MccGuire, Michael K. \& McConnell, James, Admiral Gorshkov on "Navies in War and Peace" Center for Naval Analyses Arlington VA: 1974

Westwood, James, "Soviet Naval Strategy, 1968-1978: A Reexamination" US Naval Institute Proceedings 104:5 (May 1978) pp. 114-127

Westwood, James, "Soviet Reaction to the U.S. Maritime Strategy" Naval War College Review XLI:3 (Spring 1988) pp. 62-68

Whitten, Robert, "Soviet Sea Power in Retrospect: Admiral of the Fleet Sergei G. Gorshkov and the Rise and Fall of the Soviet Navy" Journal of Slavic Military Studies 11:2 (June 1998) pp. 48-79

Yegorova, Natalia, "Stalin's Conception of Maritime Power: Revelations from the Russian Archives" The Journal of Strategic Studies 28:2 (April 2005) pp. 157-186

Zakheim, Dov S. "A Carrier for Gorshkov" Naval War College Review XXXV:1 (January-February 1982) pp. 32-39

Zubok, Vladislav M. A Failed Empire: The Soviet Union in the Cold War from Stalin to Gorbachev Chapel Hill NC: The University of North Carolina Press, 2007

\section{(iii) General}

Allison, Graham Destined for War: Can America and China Escape Thucydides's Trap? Boston MA: Houghton Mifflin Harcourt, 2017

Cable, James Gunboat Diplomacy 1919-1991 (3rd ed) Basingstoke: Macmillan, 1994

Cable, James, The Political Influence of Naval Force in History London \& Basingstoke: Macmillan, 1998

Colomb, Philip Naval Warfare. London: Allen, 1899

Corbett, Julian S. Some Principles of Maritime Strategy. With an Introduction and Notes by Eric J. Grove Annapolis MD: United States Naval Institute Press, 1988. Original work first published in 1911

Friedman, Norman, Seapower as Strategy: Navies and National Interest Annapolis MD: Naval Institute Press, 2001

Gat, Azar, A History of Military Thought: From the Enlightenment to the Cold War Oxford: Oxford University Press, 2001

Glaser, Charles L. "When Are Arms Races Dangerous? Rational versus Suboptimal Arming" International Security 28:4 (Spring 2004) pp. 44-84

Gray, Colin S. The Leverage of Sea Power: The Strategic Advantage of Navies in War New York: The Free Press, 1992

Gray, Colin S. The Navy in the Post-Cold War World University Park PA: The Pennsylvania State University Press, 1994

Gray, Colin S. \& Barnett, Roger W. (eds) Seapower and Strategy Annapolis MD: Naval Institute Press, 1989

Ireland, Bernard, Jane's Battleships of the 20th Century London: HarperCollins, 1996

Kaplan, Robert D. The Revenge of Geography: What the Map Tells us about Coming Conflicts and the Battle Against Fate New York: Random House, 2012

Keegan, John \& Wheatcroft, Andrew, Who's Who in Military History (3rd ed.) London: Routledge, 1996

Lambert, Andrew, Seapower States: Maritime Culture, Continental Empires and the Conflict That Made to Modern World New Haven CT: Yale University Press, 2018 


\section{Bibliography}

Levy, Jack S. \& Thompson, William R. "Balancing on Land and at Sea" International Security 35:1 (Summer 2010) pp. 7-43

Mahan, Alfred T. The Influence of Seapower upon History 1660-1783 Boston MA: Little, Brown \& Co, 1890

Mearsheimer, John, The Tragedy of Great Power Politics New York: Norton \& Co, 2001

O'Brien, Phillips P. Technology and Naval Combat in the Twentieth Century and Beyond London: Frank Cass, 2001

Pugh, Philip, The Cost of Seapower: The Influence of Money on Naval Affairs from 1815 to the Present Day London: Conway Maritime Press, 1986

Ross, Angus "Nationalism, Geopolitics and Naval Expansionism: From the Nineteenth Century to the Rise of China" Naval War College Review 71:4 (Autumn 2018) pp. 11-44 Speller, Ian, Understanding Naval Warfare Abingdon: Routledge, 2014

Thucydides, History of the Peloponnesian War Translated by Res Warner. London: Penguin Books, 1954

Till, Geoffrey, Seapower: A Guide for the Twenty-First Century London: Frank Cass, 2004

Westcott, Allan (ed.) Mahan on Naval Warfare: Selections from the Writings of Read Admiral Alfred T. Mahan Boston MA: Little, Brown and Company, 1942 